\title{
ARE PROFITS SHARED ACROSS BORDERS? EVIDENCE ON INTERNATIONAL RENT SHARING
}

\author{
John W. Budd \\ Matthew J. Slaughter \\ Working Paper 8014 \\ http://www.nber.org/papers/w8014 \\ NATIONAL BUREAU OF ECONOMIC RESEARCH \\ 1050 Massachusetts Avenue \\ Cambridge, MA 02138 \\ November 2000
}

For financial support Slaughter thanks the National Bureau of Economic Research, the National Science Foundation, and the Russell Sage Foundation. For helpful comments we thank Gordon Hanson, Jim Hines, Joep Konings, Andrew Oswald, Andrew Samwick, and seminar participants at Dartmouth College and University of Michigan. The views expressed in this paper are those of the author and not necessarily those of the National Bureau of Economic Research.

(C) 2000 by John W. Budd and Matthew J. Slaughter. All rights reserved. Short sections of text, not to exceed two paragraphs, may be quoted without explicit permission provided that full credit, including (C) notice, is given to the source. 
Are Profits Shared Across Borders? Evidence on International Rent Sharing John W. Budd and Matthew J. Slaughter

NBER Working Paper No. 8014

November 2000

JEL No. F23, J30

\begin{abstract}
In the literature on rent sharing in the labor market, many studies have documented a robustly positive correlation between wages for various micro-units-firms, individuals, union-firm bargaining units - with profits per worker at the level of that micro-unit's industry, where industry profits are interpreted as prosperity in the product market enjoyed by firms and available for sharing with workers. But these industry studies delineate product markets by the same country as that of the micro-units, and this implicitly closed-economy perspective may miss important international aspects of wage setting. In this paper we examine how profit sharing may be conditioned by the international linkages which help shape economic openness, by analyzing negotiated contract wages for a sample of over 1000 Canadian labor contracts spanning all manufacturing from 1980 through 1992. Our central finding is that the relevant measure of product-market prosperity, and thus the pattern of rent or profit sharing, varies significantly across international linkages including multinational ownership, union type, and trade barriers. There seems to be international rent sharing, with profit sharing across borders conditioned by institutions at both the firm and industry level.
\end{abstract}

John W. Budd

Industrial Relations Center

3-300 Carlson School of Management

University of Minnesota

Minneapolis, MN 55455

jbudd@csom.umn.edu
Matthew J. Slaughter

Department of Economics

Dartmouth College

309 Rockefeller Hall

Hanover, NH 03755

and NBER

slaughter@dartmouth.edu 


\section{Introduction}

The impact of globalization on labor-market outcomes continues to be an important concern of scholars, policy makers, and advocacy groups (e.g., see the volumes of Abowd and Freeman, 1991, and Feenstra, 2000). One particular concern is the effect on wages. Previous research analyzes the importance of foreign ownership (Aitken, et al., 1996; Feliciano and Lipsey, 1999), trade protection (Gaston and Trefler, 1994, 1995; Haskel and Slaughter, 2000), and foreign competition (Borjas and Ramey, 1995; Freeman and Katz, 1991). But whether international linkages condition how firms share profits with their workers has not been investigated.

In the literature on rent sharing in the labor market, many studies have documented a robustly positive correlation between wages for various micro-units-firms, individuals, union-firm bargaining units-with profits per worker at the level of that micro-unit's industry. These industry profits are interpreted as "prosperity in the product market" (Oswald, 1996 p. 16) enjoyed by firms and available for sharing with workers.

A common feature of these industry studies is they delineate product markets by the same country as that of the micro-units. That is, wages for micro-units located in a specific country are linked with measures of industry profitability constructed using data for operations in that same country. These industry-profit measures implicitly assume that national borders bound the product markets whose prosperity is relevant to wages. But is there international rent sharing with profits shared across borders? As a number of forces have made product and labor markets more international in recent decades, the implicitly closed-economy perspective may miss important international aspects of wage setting.

Consider, for example, the wages of automobile workers in the United States. In 1950 the United States accounted for 75 percent of total world motor vehicle output. But that share has fallen to less than 25 percent today, as production has greatly expanded in Japan, Europe, and elsewhere (Ward's Communications, 1999). When U.S. automobile workers and their firms negotiate wages, is the automobile market taken to be just the United States, or the United States plus certain other countries, or the whole world? The answer to this question may very well 
depend on a number of international linkages. One might be multinational firms. Do employees working for Honda in Marysville, $\mathrm{OH}$, focus more on automobile profits in Japan than do their counterparts working for G.M. in Flint, MI? Another linkage might be international unions. In the 1970s, the United Auto Workers (UAW) union achieved nominal-wage parity between its U.S. and Canadian workers (Budd, 1998; Yates, 1993); might this imply different behavior between unions with Canadian members and wholly-domestic unions? And trade barriers might also matter. Did Japanese voluntary export restraints alter the wage-setting behavior for U.S. auto workers?

Motivated by the questions of this example, in this paper we examine how rent or profit sharing may be conditioned by the international linkages which help shape economic openness. This focus on international linkages is the central contribution of the paper. Our wage data are negotiated contract wages for a sample of over 1000 Canadian labor contracts spanning all manufacturing from 1980 through 1992. These contracts are negotiated by a bargaining unit consisting of a union and a firm. For Canadian data, the standard profit-sharing specification includes Canadian industry profits and we start by also adding U.S. industry profits. For Canada, the United States is overwhelmingly the single biggest country in the rest of the world on many economic metrics. For example, since 1994 the United States has accounted for between 75 percent and 85 percent of all Canadian exports and about 75 percent of all imports. ${ }^{4}$ Accordingly, for our sample of Canadian wages the obvious first extension of product-market boundaries beyond Canada is to the United States.

But the importance of U.S. profits for Canadian bargaining units might depend on different international linkages. Thus, we also analyze the role of three transmission mechanisms. Two of the three indicate organizational structures: foreign ownership and international unions, based on information about the firm and union in each bargaining unit. The other captures U.S.-

\footnotetext{
${ }^{1}$ Data obtained from Statistics Canada at http://www.statcan.ca/english/Pgdb/Economy/International/gblec02a.htm.
} 
Canadian product-market integration as proxied by two industry border barriers, Canadian tariffs and U.S. transportation costs.

Our central finding is that the relevant measure of product-market prosperity, and thus the pattern of profit sharing, varies significantly with international linkages. Specifically, we have two main results. First, international linkages of organizational structure matter for how profits are shared. Higher Canadian-industry profits raise wages for employees of Canadian-owned firms and/or employees represented by a domestic union, but higher Canadian-industry profits generally have a much smaller (or no) effect on the wages of Canadian employees of U.S.-owned firms and/or employees represented by an international union. The converse holds for U.S.industry profits. Higher U.S. profits lower wages for employees of Canadian-owned firms and/or employees represented by domestic unions, but higher U.S. profits raise or have zero effect on wages for employees of U.S.-owned firms and/or employees represented by an international union. Second, we find some evidence that border barriers matter as well. Higher U.S. profits reduce wages less when Canadian tariffs are higher, while transportation costs (whose levels are much lower than tariff levels) show no such "insulating" effect on wages.

These results are robust to a number of measurement and specification issues. They have not been documented by previous research, and, taken together, they paint a richer picture of rent sharing. Profits do seem to be shared across borders: the relevant product market for wage setting extends beyond national borders, and the specific wage impacts of the prosperity of these product markets differ across multinational ownership, union type, and trade barriers. We interpret this as evidence of international rent sharing.

The organization of the paper is as follows. Section 2 briefly surveys the related literature. Section 3 motivate the empirical analysis with a discussion of the underlying theory of profit sharing. Section 4 presents our data and empirical analysis, and Section 5 concludes.

\section{Literature Survey}

This paper relates to four bodies of literature. The first and most directly relevant is that on profit sharing with workers (where profit sharing is often cited as an important cause of inter- 
industry wage differentials, e.g., Katz and Summers, 1989). Oswald (1996) carefully surveys many empirical studies in this literature. Among these studies, ours is closely related to Christofides and Oswald (1992), who also use Canadian bargaining-unit wages and find a positive link between wages and Canadian industry profits. It is also closely related to Abowd and Lemieux (1991, 1993), who also use bargaining-unit data but relate these wages to industry product prices and shipments; and to Blanchflower et al. (1996), who link various measures of U.S. wages with U.S. industry profits. Again, we build on these studies by examining how profit sharing varies with different international linkages.

Second, our interest in whether multinational ownership conditions profit sharing is related to other studies of how multinationals differ from their domestic counterparts. Globerman et al. (1994) report that foreign affiliates in Canada pay higher wages than do Canadian establishments, but that this differential is not due to ownership per se but rather to foreign affiliates being larger and more capital intensive. Howenstine and Zeile (1994), Doms and Jensen (1998), and Feliciano and Lipsey (1999) find the same for U.S. manufacturing: foreign affiliates pay more than U.S. owned establishments, but only because of scale, capital-use, and technology differentials rather than ownership per se. But Doms and Jensen also report that multinational establishments, be they U.S. or foreign owned, pay significantly more than purely domestic plants do even controlling for other performance factors. Aitken et al. (1996) document a pay-ownership differential for Mexico and Venezuela as well as the United States. None of these studies examines whether foreign ownership implies different profit sharing, or whether profitability in the parent country affects wages in the foreign affiliate. The answers to these question matter a lot for how multinationals operate in host countries and whether government policies should court these firms (e.g., Svejnar and Smith, 1984).

\footnotetext{
2 Our empirical focus is on profit sharing with unionized workers. We do not consider compensation for CEOs and other corporate officers. There is now a large literature on the role of profit sharing in executive compensation (see Murphy, 1999, for a survey). We also do not consider profit sharing with debt and/or equity holders. Hines (1996) finds that U.S. firms pay dividends out of their foreign profits at three times the rate they do out of their domestic profits; his distinction between foreign and domestic profits is in the same spirit of our study.
} 
Third, our focus on international unions extends other studies of the labor-market impacts of international unions and enriches the literature on unions more generally. In Canadian manufacturing, roughly half of the unionized bargaining units are represented by an international union - i.e., a union headquartered in the United States (Budd, 1998). ${ }^{3}$ Unions are complex political institutions, and case-study evidence suggests that international unions may be an important transmission mechanism for importing U.S. conditions into Canadian wage determination (Budd, 1998; Crispo, 1967; Yates, 1993), but international unions have been overlooked by research on globalization and labor market outcomes.

Finally, as stated in the introduction, our work is related to the large recent literature on globalization and labor-market outcomes. This literature is far too large to summarize here (see Slaughter, 1999 for a discussion). But one point of contrast is that much of the empirical work in this area has followed from the perfectly competitive Heckscher-Ohlin trade model in which all sectors earn zero profits and all workers earn their marginal revenue products. Thus, our focus on profit sharing is closer to studies such as Borjas and Ramey (1995), who investigate whether import competition squeezes rents paid to U.S. less-skilled workers in imperfectly competitive industries, and Gaston and Trefler (1995), who examine a cross-section of U.S. unionized workers and find U.S. tariffs to be negatively correlated with industry wage premia.

\section{Empirical Framework}

\section{3a. Motivating Theory and Empirical Strategy}

The notion of profit sharing between workers and their firm can be easily formalized in a bargaining framework. Consider a situation in which risk-neutral workers enjoy some negotiating power, $\phi$, for bargaining with their firm over their wage, w. In a Nash bargaining setting, the maximization problem for the negotiation is given by

$$
\text { (1) Maximize } \phi \log \left\{\left[\mathrm{u}(\mathrm{w})-\mathrm{u}\left(\mathrm{w}_{\mathrm{o}}\right)\right] \mathrm{n}\right\}+(1-\phi) \log (\pi)
$$

\footnotetext{
3 Despite the standard label of "international union," from a Canadian perspective these unions are essentially "foreign unions." They are headquartered in the United States, and the Canadian membership is typically a small proportion of the total.
} 
where $\mathrm{u}(\mathrm{w})$ is worker utility from wage $\mathrm{w} ; \mathrm{w}_{\mathrm{o}}$ represents the outside wage available to workers if bargaining breaks down; $\mathrm{n}$ is the number of workers; and $\pi$ is profits defined as firm revenue less its wagebill. From (1) comes the following expression for the negotiated wage outcome.

$$
\text { (2) } w \approx w_{o}+\left(\frac{\phi}{1-\phi}\right)\left(\frac{\pi}{n}\right)
$$

The equilibrium wage depends on the outside wage option and on profits per worker, where the pass-through of profits to wages depends on relative bargaining power. Oswald (1996) derives (2); Svejnar (1986) derives (2) and a more general expression for the case of risk-averse workers.

Equation (2) is actually quite general. As it is derived directly from the optimization problem in (1), it holds for any bargaining framework which can be characterized by (1). But equation (2) also obtains from many other wage-setting situations. As Oswald (1996) demonstrates, it can be derived from a perfectly-competitive setting in which short-run labor-mobility frictions make the labor-supply schedule slope upward; or from a labor-contract model in which both workers and firms are risk-averse, and thus optimally share profits in boom times; or from various models of fairness in which not sharing profits is perceived to be somehow unjust.

Many rent-sharing studies cited in Section 2 base their empirical analysis on equation (2), with the repeated finding of a robustly positive correlation between wages for various microunits_firms, individuals, union-firm bargaining units—with profits per worker at the level of that micro-unit's industry. So if b indexes micro-units (such as bargaining units as in our data), $i$ industries, and time, the common approach is to estimate an equation like the following.

$$
\text { (3) } \mathrm{w}_{\mathrm{bit}}=\beta(\pi / \mathrm{n})_{\mathrm{it}}+\gamma Z_{\mathrm{bit}}+\mathrm{e}_{\mathrm{bit}} \text {. }
$$

Here $\mathrm{Z}_{\mathrm{bit}}$ is a vector of wage determinants other than profitability which may vary by microunits, industries, and/or time; $(\pi / \mathrm{n})_{\mathrm{it}}$ is industry-level profits per worker; $\mathrm{e}_{\mathrm{bit}}$ is an error term; and the parameter of interest $\beta$ is commonly estimated to be significantly greater than zero.

All studies using (3) delineate product markets by the same country as that of the micro-unit. That is, $(\pi / \mathrm{n})_{\text {it }}$ is constructed using data from the same country as the micro unit b (e.g., wages for U.S. union contracts are regressed on profits per worker for industries located in the United 
States). As stated in the introduction, this assumption that national borders bound the product markets whose prosperity is relevant to wages might not square with the many forces that have made product and labor markets in recent decades. Accordingly, this implicitly closed-economy perspective may miss important international aspects of wage setting. Our analysis extends the framework in (3) to test for international rent sharing.

First, we want to examine whether the relevant product market for wage negotiations goes beyond national borders. As product markets become more integrated across countries—and as many industries in many countries account for an ever-smaller share of world output for those industries - this possibility seems quite plausible. So if there are two countries, home (h) and foreign (f), this issue suggests the following regression specification.

$$
\text { (4) } \mathrm{w}_{\mathrm{bit}}=\beta(\pi / \mathrm{n})^{\mathrm{h}_{\mathrm{it}}}+\delta(\pi / \mathrm{n})_{\mathrm{it}}+\gamma \mathrm{Z}_{\mathrm{bit}}+\mathrm{e}_{\mathrm{bit}} \text {. }
$$

For micro-units located in home, we want to allow wages to depend not just on home industry profits but on foreign industry profits as well. We also want to allow different pass-through for different countries' profits (i.e., to allow $\beta \neq \delta$ ).

Second, we want to examine whether pass-through varies with international linkages. One important linkage may be being part of a multinational firm. On the one hand, as discussed in Section 2 multinationals appear to pay higher wages than observationally equivalent domestic firms, a fact which may be consistent with multinationals enjoying and sharing with workers higher profits thanks to greater product-market power. On the other hand, Rodrik (1997) has argued that international capital mobility grants multinationals more bargaining power over workers, thanks to a more-plausible threat to relocate activity to other countries. When considering profits from more than one country, there may be interactions with ownership status. For example, Canadian affiliates of U.S. multinationals may be more sensitive to U.S. profits than are purely domestic Canadian firms.

Another important linkage may be being part of an international union. Budd (1998) catalogs several differences between domestic and international unions that may matter for profit sharing. International unions may enjoy more bargaining power than purely domestic unions 
thanks to greater resources and bargaining experience. Also, to the extent that the leaders of international unions feel compelled to satisfy members located in many countries, how wages vary with other-country profits may differ between domestic and international unions. For example, if profits are unexpectedly lower at home, leaders of international unions may feel compelled to spread this hardship among all members regardless of location. This may mean lower foreign wages for members of international unions-but not for members of purely domestic unions.

A third international linkage which may matter for profit sharing is trade barriers. In principle, the degree to which the closed-economy perspective implicit in equation (3) is inappropriate depends largely on how insulated a country's product markets are from the rest of the world. Border barriers such as tariffs and transportation costs insulate domestic firms from foreign competition; in the extreme, prohibitive barriers make (3) match the textbook case of a country in autarky. Exactly how prohibitive border barriers are for the empirically relevant case of less-than-free trade depends on market structure (e.g., Helpman and Krugman, 1989), but a first-pass prediction is that higher border barriers mean more insulation for home micro-units and thus less pass-through from foreign profits to home wages.

Taken together, the preceding discussion suggests that equation (4) should be extended even further to allow interactions between profits and various international linkages. Let $\mathbb{I L}_{\mathrm{bit}}$ be a set of dichotomous variables coded 1 to indicate the presence of some international linkage and 0 otherwise (or coded continuously for quantifiable linkages such as trade barriers). Then this information can be added to (4) to obtain a more general specification:

$$
\begin{aligned}
(5) \mathrm{w}_{\text {bit }}=\alpha\left(\mathrm{IL}_{\mathrm{bit}}\right) & +\beta(\pi / \mathrm{n})^{\mathrm{h}_{\mathrm{it}}}+\beta_{\mathrm{IL}}\left[(\pi / \mathrm{n})^{\mathrm{h}_{\mathrm{it}}} \times\left(\mathrm{IL}_{\mathrm{bit}}\right)\right] \\
& +\delta(\pi / \mathrm{n})^{\mathrm{f}}{ }_{\mathrm{it}}+\delta_{\mathrm{IL}}\left[(\pi / \mathrm{n})^{\mathrm{f}} \mathrm{it}_{\mathrm{it}} \times\left(\mathrm{IL}_{\mathrm{bit}}\right)\right]+\gamma \mathrm{Z}_{\mathrm{bit}}+\mathrm{e}_{\mathrm{bit}}
\end{aligned}
$$

In (5), we enter these international linkages both individually and interacted with our profits measures. Our pass-through parameters of interest are now subscripted, $\beta_{\mathrm{IL}}$ and $\delta_{\mathrm{IL}}$, to indicate that we now allow these quantities of interest to vary not just by country but also by linkages. 
We will estimate several specifications of the form given in equation (5). We now turn to a description of our data and econometric issues.

\section{3b. Data, Measurement, and Variable Construction}

To estimate equation (5) we need micro-unit-level data on wages, industry-level data on profits per worker for multiple countries, data on international linkages at either the micro-unit level or industry level, and various control regressors at various aggregation levels. In principle these data could span all sectors, but we have data for manufacturing sectors only.

The core of the data is a wage-settlement file for Canadian collective-bargaining agreements covering 500 workers or more in manufacturing collected by Human Resources Development

Canada. 4 Wages are reported at the bargaining-unit level of observation, where each bargaining unit consists of a union and a firm. We use the reported starting base hourly wage rate (typically the wage of the lowest paid bargaining-unit classification) for the beginning of each contract, deflated by the Canadian consumer price index (CPI). Thus our wage measure, $\mathrm{w}_{\mathrm{bit}}$, is the logarithm of the real hourly wage for bargaining unit $b$ in industry $i$ at the start of the contract going into effect in year $t$.

In addition to the wage rate, the Human Resources Development Canada file also contains the name of the company and the union, the primary industry of the firm, the number of employees covered by the contract, contract duration, and the location (province) of the bargaining unit. By combining this additional information with outside data sources, we constructed the various regressors in (5). We end up with an unbalanced panel of 1014 bargaining-unit/year observations spanning 242 bargaining units and 12 years, 1980 to 1992. The data set includes observations from 54 different 3-digit manufacturing industries. Note that different bargaining units have different numbers of observations and also different start years for new contracts. The average contract duration is 30 months.

\footnotetext{
4 Abowd and Lemieux (1991, 1993) and Christofides and Oswald (1992) use earlier versions of this same file.
} 
To construct industry profits per worker from Canadian operations, $(\pi / n){ }^{h_{i t}}$, we follow Blanchflower et al. (1996). This study proposed three possible measures of industry profits.

$$
\begin{aligned}
& \text { Profit } 1=(\text { Value Added }- \text { Payroll }) / C P I \text { [per employee] } \\
& \text { Profit } 2=\text { Profit } 1-\text { Depreciation [per employee] } \\
& \text { Profit } 3=\text { Profit } 2-\text { Opportunity Cost of Capital [per employee] }
\end{aligned}
$$

Profit2 adjusts simple real profits (Profit1) for depreciation, where Depreciation $\mathrm{t}_{\mathrm{t}} \equiv($ Capital Stock $_{\mathrm{t}}-$ Capital Stock $_{\mathrm{t}+1}+$ Investment $_{\mathrm{t}}$ ). Profit3 further accounts for the opportunity cost of capital, where Opportunity $\mathrm{CoC}_{\mathrm{t}} \equiv\left(\right.$ Risk-Free Interest Rate $-\mathrm{CPI} \%$ Change $\left._{\mathrm{t}}\right) \mathrm{x}\left(\right.$ Capital Stock $\left._{\mathrm{t}}\right)$. We constructed all three profit measures; data on CPI and treasury-security interest rates (our proxy for the risk-free interest rate) come from the International Monetary Fund, and all other industry data come from data provided by Statistics Canada.

In constructing the profit measures, we maintained as much industry disaggregation as possible. For 31 of the 54 3-digit industries in the wage settlements data, there was sufficient data to construct profits at the 3-digit level; for 22 industries data availability only permitted profit construction at the 2-digit level; the remaining industry is a combination of 2- and 3-digit measures, depending on the year. The sample correlation among all three measures is quite high, so our empirical results are robust to which measure we use. In the tables below, we report baseline specifications using Profit2.

For industry profits per worker outside Canada, $(\pi / \mathrm{n})^{\mathrm{f}}{ }_{\mathrm{it}}$, in principle we could include all countries in the rest of the world. In practice, data constraints limit us to analyzing U.S. industry profits. As discussed in the introduction, on many economic metrics the United States is overwhelmingly the economic component of the rest of the world from Canada's perspective. U.S. profits are constructed analogous to our Canadian measures using data from the National Bureau of Economic Research's Manufacturing Productivity Data Base, an industry-year panel 
of 450 4-digit U.S. SIC sectors (Bartelsman and Gray, 1996). To maintain comparability with the Canadian data, U.S. profit measures were constructed at the same 2- and 3-digit levels. 5

As with the three Canadian profit measures, sample correlations among three U.S. profit measures are high, so we report baseline specifications using Profit2. Our baseline results measure U.S. profits in real U.S. dollars; we also report measures in real Canadian dollars.

We construct four different variables to capture international linkages, $\mathrm{IL}_{\mathrm{bit}}$. One is U.S. ownership (i.e., foreign ownership, since the home country is Canada). Using firm names reported in the wage-data file, we determined the nationality of each firm's majority owner to create various firm categories: parent of a Canadian-headquartered multinational, a purely domestic Canadian firm, affiliate of a U.S.-headquartered multinational, or affiliate of a nonU.S.-headquartered multinational. To determine nationality of ownership, we relied on various corporate directories and paid careful attention to ownership changes. ${ }^{7}$ We dropped from our sample affiliates of non-U.S.-headquartered multinationals, both because we measure $(\pi / n){ }_{i t}$ only for the United States and because we do not have data on linkages for countries other than the United States (e.g., all international unions are U.S.-headquartered). These dropped affiliates were only about $9 \%$ of the full data sample.

A second measure of international linkages is international unions, i.e., U.S.-headquartered unions. The wage-data file reports the union representing each bargaining unit. Using information on international status from Labour Canada (various issues), we can identify each observation's union as either international or domestic.

\footnotetext{
5 Since this time frame pre-dates the common North American Industry Classification System, we needed to create a concordance between 3-digit Canadian SIC codes and 3-digit U.S. SIC codes (as well as between the 1970 and 1980 codes for Canada and the 1972 and 1987 revisions for the United States). The starting point was Statistics Canada (1991), but information on the products produced by specific bargaining units was used when ambiguities arose. In two instances, the 3-digit Canadian SIC code maps into two U.S. categories and so weighted averages of the two U.S. industry measures were used to construct a single industry measure.

6 Corporate parentage was identified using International Directory of Corporate Affiliations (Skokie, IL: National Register Publishing Company), Who Owns Whom (London: O.W. Roskill), Moody's Industrial Manual (New York: Moody's Investors Service), Moody's Public Utility Manual (New York: Moody's Investors Service), Moody's International Utility Manual (New York: Moody's Investors Service), Survey of Industrials (Toronto: Financial Post Corporation Service Group) and The Blue Book of Canadian Business (Toronto: Canadian Newspaper Services International).
} 
Our other international linkages are border barriers: tariffs and transportation costs. Tariffs measure the ad valorem bilateral tariff rate imposed by Canada on U.S. imports. These data were constructed by using the rates from Deardorff and Stern (1990, Tables A7 and A8) for 1976 and 1987 and applying the relevant negotiated tariff reductions for other years. ${ }^{4}$ Our transportation costs are calculated as the difference between imports into the United States valued cost, insurance, freight (c.i.f.) and imports valued "free on board"(f.o.b.), all as a share of imports valued f.o.b. This quantity is an ad valorem transportation cost capturing the actual expenses incurred shipping and insuring goods. We use U.S. data because we do not have c.i.f. and f.o.b. import data for Canada. Tariffs and transportation costs vary over time and industry.

Finally, for the other measured determinants of wages, $\mathrm{Z}_{\mathrm{bit}}$, we experimented with a large number of variables used in studies such as Budd (1998) and Christofides and Oswald (1992). In the tables below, our baseline specifications include the following variables: contract duration, number of employees, industry average hourly earnings, industry employment growth, the provincial unemployment rate, and provincial average weekly earnings as well as industry, province, and year effects. All results are robust to the exact set of variables in $\mathrm{Z}_{\mathrm{bit}}$.

\section{3c. Econometric Issues}

Before presenting our estimation results for equation (5), there are three important econometric issues to mention. First is the possibility of omitted-variables bias, in particular because in (5) we correlate bargaining-unit wages with industry profitability but include no measure of bargaining-unit profitability. As with many related studies (Christofides and Oswald, 1992; Abowd and Lemieux, 1993; and Blanchflower et al., 1996), this specification choice is largely due to insufficient firm-level data. Moreover, as will be seen below, 40 percent of the observations involve a U.S. parent company, and only rarely do these companies report Canadaonly profits. That said, industry profits may be a measure of product-market prosperity

\footnotetext{
7 More specifically, the GATT Tokyo Round reductions were done in eight equal steps between 1980 and 1987 tariff rates for each year are straightforward to construct using the starting and ending values. The 1987 Free Trade Agreement removed all U.S.-Canadian tariffs between 1989 and 1998. These reductions were not uniform and we used the reduction schedule in Magun et al. (1988) to calculate each industry's tariff rate for each year.
} 
uncontaminated by profitability shocks idiosyncratic to the firm, and thus may be an important focal point for unions and/or firms in collective bargaining. Traditional union rhetoric is that differences in ability to pay across firms arise due to differences in management, not workers, as illustrated by the UAW's rejection of the idea that "inefficiency in management should be subsidized out of workers' living standards" (MacDonald, 1963, p. 215). Thus, to maintain parity with Ford and other worldwide competitors, GM may have to pay high wages when the overall auto industry booms even if GM itself is faring relatively poorly.

More generally, one can imagine how wage setting may depend on profits at many levels: the establishment, the product division within a firm for multi-product firms; the geographic division within a firm for multinationals; the overall firm; the industry in the residence country; and the industry worldwide. Ideally, we could measure and analyze profits at all these levels. But in reality we simply do not have the establishment, firm, and industry detail to do this. This data problem faces all related profit-sharing studies we know of, and we think our specification in equation (5) tries to move existing work closer to this ideal. Note the error term $e_{b i t}$ needs to account for the fact that profits regressors vary at a more-aggregated level than the regressand; we report results for standard errors which are robust to arbitrary forms of heteroskedasticity.

A second econometric issue is endogeneity. Wages and profits are, of course, simultaneously determined. To the extent that higher wages mean lower profits, ceteris paribus, equation (5) will understate the true pass-through from profits to wages. Instrumenting is one possible solution, but this requires data on one or more variables which are positively correlated with profits yet uncorrelated with $\mathrm{e}_{\mathrm{bit}}$. Oswald (1996) discusses the difficulties in finding ex ante plausible instruments for profits. The alternative solution is to lag the profits regressors, under the assumption that shocks to profits take time to pass through to wages (e.g., because of multiyear contracts). Christofides and Oswald (1992) report results lagging profits one year; Blanchflower et al. (1996) find the strongest results for three-year lags. We split the difference

\footnotetext{
8 In the literature on profit sharing, Svejnar (1986), Currie and McConnell (1992), and Hildreth and Oswald (1997) link firmlevel wages with firm-level profits as reported in corporate annual reports. But these studies do not include industry-level profits.
} 
and report our baseline specifications lagging $(\pi / \mathrm{n})^{\mathrm{h}_{i t}}$ and $(\pi / \mathrm{n})^{\mathrm{f}} \mathrm{ft}_{\mathrm{it}}$ two years. Both one-year and three-year lags were also used extensively; we report some results from three-year lags. We also attempted instrumenting for profits using exchange rates, and will discuss this below.

The third econometric issue is how best to exploit the panel nature of our data. In principle, our baseline specifications could include a full set of bargaining-unit fixed effects. In practice, bargaining-unit fixed effects are highly collinear with two of our regressors of greatest interest, our indicator variables for multinational ownership and international union. This is because our data contain very few bargaining units which switch ownership and/or union representation over time. Of the 242 bargaining units in our full sample, only 10 ever change ownership status and 33 ever change union status. ${ }^{\text {This }}$ is not surprising, since we average only about four observations over time per bargaining unit. Given this collinearity problem, in our baseline specifications we include a full set of industry, province, and year fixed effects (with coefficient estimates not reported, for brevity). Some results using bargaining-unit fixed effects will be reported, to help gauge the robustness of other regressors.

\section{Empirical Results}

\section{4a. Profit Sharing and International Organizations}

Table 1 reports summary statistics for our key variables of interest. Recall that the data cover 1,014 union wage settlements for 242 union-firm pairs in Canadian manufacturing from 1980 to 1992. Column 1 reports sample means (and standard deviations) for our full sample. To preview some of the variation across our international linkages, columns 2 and 3 report means (and standard deviations) for the subsamples of Canadian-owned firms and U.S.-owned firms, respectively. Column 4 reports t-tests for whether means differ between the subsamples.

Nearly three-quarters of the observations in the overall sample have at least one of the organizational-structure international linkages of interest: 40.1 percent are part of U.S.-owned multinationals and 53.1 percent of observations involve international unions. Also, of the

\footnotetext{
${ }^{9}$ More than five percent of the bargaining units experience an ownership change, but if parent nationality remains constant then our ownership indicators do not change. Moreover, if a firm is bought from or sold to a non-U.S. international company, the bargaining unit enters or leaves the data set.
} 
Canadian-owned firms, 46.0 percent are Canadian-headquartered multinationals. Tariff levels are much higher than transportation costs. And there appear to be notable differences among the two ownership subsamples: U.S. affiliates are located in faster-growth industries, lowerunemployment regions, and industries with lower border barriers (transportation costs and tariff rates). Average wages in U.S. affiliates are slightly lower than in domestically-owned firms, but this difference is not statistically significant and does not control for any observable differences.

Tables 2 through 6 investigate the role of foreign ownership and international unions, our organizational structures. In Tables 7 through 10 we add to the analysis tariffs and transportation costs, our border barriers. In all tables, columns represent different specifications while rows represent different regressors, with cells reporting coefficient estimates (and heteroskedasticconsistent standard errors) from OLS estimates.

Table 2 reports initial estimation results for equations (3), (4), and (5). Column 1 starts with equation (3), to match the typical profit-sharing specification used in the previous literature. Other than the $Z_{\text {bit }}$ regressors, the only regressor is $(\pi / \mathrm{n})^{\mathrm{h}_{i t}}$. As in related studies, this variable is significantly positive, indicating higher industry profits in Canada pass through to higher wage settlements in Canada, and precisely estimated $(t$ statistic $=4.384)$. Since the mean of the Canadian profits variable is 0.036 (see Table 1), the column 1 coefficient of 1.583 implies a profit elasticity of wages of 0.06 . Thus, a doubling of industry profits would boost real wages by 6 percent. This is very similar to profit elasticities estimated previously, e.g., the range of 0.06 to 0.08 estimated by Blanchflower et al. (1996) for U.S. manufacturing wages.

Column 2 moves to equation (4), which adds the regressor $(\pi / n){ }^{f_{i t}}$. The coefficient on U.S. profits is insignificantly different from zero, while that on Canadian profits is basically unchanged. Column 3 adds foreign ownership using a categorical variable, U.S. Parent, equal to one if the bargaining unit is an affiliate of a U.S.-headquartered multinational, and zero otherwise. This column also adds a categorical variable, International Union, equal to one if the bargaining unit involves an international union and zero if it involves a purely domestic union. The coefficient estimate on U.S. Parent is insignificant, while that on International Union is 
significantly negative (consistent with Budd, 1998). The profitability coefficients are basically unchanged from column 2 .

Were one to stop at this point, one might conclude that international linkages do not matter for rent sharing. But column 3 does not interact profits per worker with U.S. Parent or International Union, as in equation (5). Columns 4 through 6 do this, and reveal strong evidence that international linkages condition the pattern of profit sharing.

First, consider column 4 in which both Canadian and U.S. industry profits are interacted with U.S. Parent. For domestic Canadian firms, the responsiveness of wages to Canadian industry profits has increased substantially from our earlier estimates which pooled all firms. Our point estimate has risen from 1.583 in column 1 to 2.740 , implying a rise in the profits-wages elasticity from 0.06 to 0.10 . U.S. affiliates show significantly less wage responsiveness to Canadian industry profits than their Canadian-owned counterparts, as indicated by the -1.708 coefficient $(t$ statistic $=2.530$ ). The absolute wage effect for U.S. affiliates is positive, with an elasticity of 0.04, but this effect is only borderline significantly different from (an $F$ test for the sum of the coefficients on Canadian profits and Canadian profits interacted with U.S. Parent equaling zero has p-value 0.093).

The responsiveness to U.S. industry profits also varies with ownership. Our pooled estimates in Columns (2) and (3) suggested no wage effects from U.S. industry profits. But column 4 indicates that for domestic Canadian firms, wages are significantly lower the higher are U.S. industry profits, with an implied elasticity of -0.08 . In contrast, wages at U.S. affiliates are hurt much less by higher U.S. industry profits, as indicated by the significant point estimate 2.399 ( $t$ statistic $=3.602$ ). The absolute wage effect for U.S. affiliates is positive, with an elasticity of 0.01, but not significantly so (an $F$ test for the sum of the coefficients on U.S. profits and U.S. profits interacted with U.S. Parent equaling zero has p-value 0.595).

The overall rent-sharing story in column 4 is much richer than has been previously documented. The positive Canadian profits-Canadian companies linkage is the standard profitsharing situation: boom times in the product market create surpluses for firms to share with 
workers (Blanchflower et al., 1996; Christofides and Oswald, 1992). The weaker Canadian profits-U.S. affiliates linkage suggests the standard profit-sharing situation is somehow tempered by the additional complexities of multinational ownership. One plausible mechanism might be that U.S. parents feel competitive pressure when Canadian industry profits are high, and thus try to restrain wages firm-wide. This restraint might mute the upward pressure from standard rent sharing, and therefore yield a lower responsiveness of Canadian wages to Canadian profits in U.S.-owned firms than in Canadian-owned firms. Alternatively, if there are other factors (e.g., firm-wide compensation policies) that affect wages in foreign-owned firms more than whollydomestic entities, then wages at U.S. affiliates might be less responsive to Canadian profits.

The negative U.S. profits-Canadian companies linkage again suggests international competitive forces: boom times in U.S. industry pressures Canadian firms to restrain wages. The U.S. affiliates are presumably subjected to this pressure, but if there is international rent sharing then higher U.S. profits would also raise wages. The marginally positive U.S. profitsU.S. affiliates linkage is consistent with these two features offsetting each other: higher U.S. profits increase wages, by virtue of international rent sharing through the multinational linkage, but also decrease wages, by virtue of product-market competition in Canada.

Column 5 of Table 2 examines our other international organizational linkage - international unions. As with column 4, rent sharing varies across groups. Higher Canadian industry profits imply significantly higher wages for domestic unions-again, much higher than our earlier pooled estimates—but insignificantly higher wages for international unions. Higher U.S. industry profits imply significantly lower wages for domestic unions-again, different from our earlier pooled estimates_-but higher wages for international unions, albeit insignificantly so. Using the point estimates in column 5, a 10 percent increase in Canadian profits increases domestic-union wages by 0.9 percent, but increases international-union wages by only 0.1 percent. A 10 percent increase in U.S. profits decreases domestic-union wages by 0.5 percent, but raises wages in international unions by 0.3 percent. For both profits measures, the differential wage response between international and domestic unions is statistically significant 
(as indicated by the two interaction variables), but the overall wage effect for international unions is not statistically significant.

As with foreign ownership, union structure conditions profit sharing. One possible explanation is that for domestic unions, higher Canadian profits are seen as a boon to be shared, whereas higher U.S. profits are seen as a pressure to be endured. For international unions, by virtue of representing both Canadian and U.S. workers, higher profits might cut both ways within the membership, with no clear net wage implications. The significant differences between domestic and international unions are consistent with expressed dissatisfaction with international unions in Canada and the importation of U.S. goals and constraints into Canadian collective bargaining (Budd, 1998; Crispo, 1967; Yates, 1993). A prominent example was the automobile industry in the early 1980s, in which the U.S. UAW leadership was accused of blocking wage increases for its Canadian members during the U.S. auto slump.

Our robustness checks start with Column 6 of Table 2, where we report the results of including both the U.S. Parent and International Union profit interactions in a single regression. This does not change the pattern of results, and each of the organizational structures appears to matter (in that all four interaction terms are significantly different from zero) even with the other included in the specification. If anything, profit-sharing patterns for "purely Canadian" bargaining units-i.e., those with both a Canadian firm and a domestic union-are even larger than the baselines of the previous two specifications.

Tables 3 and 4 report a number of robustness checks on the role of foreign ownership and international unions, respectively. In each table, the first column reports the relevant baseline specification from Table 2. Columns 2 through 4 report results using alternative profit measures (see Section 3b): our baseline profit variable lagged three years rather than two; an alternative

10 The $F$ test for the sum of the coefficients on Canadian profits and Canadian profits interacted with International Union equaling zero has p-value 0.75 . The $F$ test for the sum of the coefficients on U.S. profits and U.S. profits interacted with International Union equaling zero has p-value 0.31 . 
profit variable lagged two years; and our baseline profit variable measured in Canadian rather than U.S. dollars. All results are qualitatively as before.

As an additional robustness check, recall that many of the bargaining pairs in our data appear more than once as they negotiate new contracts. Column 5 of Tables 3 and 4 reports results from including in $\mathrm{Z}_{\mathrm{bit}}$ in equation (5) a full set of bargaining-unit fixed effects, rather than the full set of industry/province/year effects. In broad terms, the pattern of results is similar to the OLS specifications. In Table 3, Canadian profits for Canadian firms is significantly positive, U.S. profits for Canadian firms is significantly negative, and the interacted profit variables with U.S. Parent lessen the Canadian profits effect and increase the U.S. profits effect. However, the interacted coefficients are imprecisely estimated. This is to be expected, as controlling for bargaining-unit fixed effects drastically reduces the independent variation in the key U.S. Parent variable. In fact, given that only 5 percent of the bargaining units change ownership status, it is surprising that the interacted U.S.-profits coefficient is even close to statistical significance (pvalue $=0.173$ ). Things look similar in Table 4 . The coefficient estimates are smaller and the standard errors larger, with identification of the interaction terms again tenuous because of so few union-status switchers.

Column 6 of Tables 3 and 4 reports results for the OLS baseline specification estimated on a sample excluding the auto industry. Because of the extent of cross-border integration stemming from the 1965 Auto Pact, we want to ensure that our results are not driven by this single industry. As can be seen, the results are unchanged.

Table 5 estimates equation (5) separately for different international-organization subsamples. These split-sample results are more general than the interacted results of Tables 2-4, because coefficients on all regressors are now permitted to vary across groups. The findings are qualitatively identical as before. In columns 1 and 2, the sample is split between Canadian firms and U.S. affiliates. Canadian profits have a significantly positive wage effect only for Canadian firms. As discussed earlier, this is consistent with standard rent-sharing theories for domestic firms and a more complicated wage-setting process for foreign-owned firms. U.S. profits are 
significantly negative for Canadian firms, but are borderline significantly positive for U.S. affiliates. As discussed earlier, this suggests that a positive U.S. economic climate pressures Canadian firms and thus their workers. In contrast, higher U.S. profits benefits workers in U.S. affiliates thanks to international rent sharing but also hurts them via the product-market competition in Canada: thus the magnitude of this last effect is smaller than the baseline Canadian profits-Canadian firms rent-sharing effect.

Columns 3 and 4 of Table 5 split the sample by international-union status. The results are similar to those in columns 1 and 2, but with less-precise estimates on U.S. profits. The positive effect of Canadian profits on wages for workers represented by a domestic union is consistent with standard rent-sharing theories. The other profit estimate significant at the 10 percent level is U.S. profits for international-union wages, again is consistent with international unions importing the sharing of U.S. profits into Canadian wage determination.

Our final set of robustness checks is in Table 6, which presents two different manipulations of the international organizational linkage idea. First, thus far the variable U.S. Parent has combined two kinds of Canadian-owned firms as the omitted category: those that are parents of Canadian-headquartered multinationals, and those that are purely domestic firms. In column 1, an additional Canadian-multinational variable is added and interacted with Canadian and U.S. profits. For U.S. profits, the results are as before. Interestingly, the non-interacted dummy variables indicate that holding all else constant, wholly domestic Canadian firms have the highest wage levels on average.

To investigate the combined effect of ownership and union status, rather than each institution separately, column 2 of Table 6 separates out bargaining units that involve both a U.S. affiliate and an international union. The combined effect of U.S. ownership and union status is stronger than each individually, as indicated by the much larger coefficient estimates on the two interaction terms than in earlier tables. In fact, here the absolute effect of U.S. profits in the presence of both a U.S. parent and international union is significantly positive, not insignificantly 
positive as in earlier tables. 1 This suggests that international linkages for profit sharing are particularly important when jointly present: U.S. firms bring U.S. conditions into Canada via international rent sharing, and the added presence of U.S.-based labor unions magnify this.

\section{4b. Profit Sharing and Trade Barriers}

In Table 7, we turn our attention to our other two measures of international linkages, the border barriers. We have industry-level data on ad valorem transportation costs and tariffs for Canada, higher values of which indicate larger trade barriers (see Section $3 \mathrm{~b}$ for details on data construction). Column 1 re-reports the (non-interacted) baseline specification from column 3 of Table 2. Column 2 adds transportation costs; the estimate of 0.034 indicates wages tend to be higher in industries with higher transport costs. Column 3 interacts transportation costs with both Canadian and U.S. industry profits. Canadian profits is again significantly positive, and U.S. profits is marginally negative ( $\mathrm{p}$-value $=0.062$ ). The interacted coefficients are very imprecisely estimated, suggesting rent sharing does not systematically vary with transport costs.

Columns 4 and 5 repeat the analysis for tariffs. In column 4, tariffs are not significantly correlated with wages. Column 5 interacts tariffs with Canadian and U.S. industry profits, and a richer picture emerges. Higher Canadian industry profits imply higher Canadian wages, with no significant variation in this rent sharing across tariff levels. But tariffs do matter for the sharing of U.S. industry profits, as indicated by the significantly negative coefficient for U.S. industry profits, along with the significantly positive coefficient on U.S. industry profits interacted with tariffs. In low-tariff industries higher U.S. industry profits imply significantly lower Canadian wages, but as tariffs rise this wage pressure diminishes. The implied profits-wage elasticity goes from -0.13 in unprotected sectors to just above zero in the most heavily protected sectors (crossing zero at the $90^{\text {th }}$ percentile for tariffs).

Taken together, the estimates in Table 7 are consistent with our earlier finding that higher U.S. industry profits can put downward pressure on Canadian wages-but with the new finding

\footnotetext{
11 The $F$ test for the sum of the coefficients on U.S. profits and U.S. profits interacted with both U.S. Parent and International Union equaling zero has p-value $<0.001$.
} 
that higher tariffs can mitigate this pressure. This is broadly plausible, as standard trade theory shows quite clearly that trade barriers insulate domestic firms from foreign competition. That tariffs but not transport costs matter might reflect the fact that average transport costs are much lower: just under 1 percent versus over 7 percent (Table 1), with free trade at zero.

Robustness checks analogous to Tables 3 and 4 are reported in Table 8 and 9. Our findings are broadly the same: transport costs don't matter, but tariffs do. In Table 8, none of the interaction terms with transportation costs are significantly different from zero. For tariffs, in Table 9 all specifications but the fixed-effect specification in column 5 are qualitatively the same as those in Table 7.

The final robustness check we report is to verify that the international-organization variables and the border-barrier variables are not estimating the same underlying effect. Table 10 presents regression results from including both the foreign-parent or international-union interacted variables and the interacted border-barrier variables. In all columns, international-organization interactions are all significantly different from zero, consistent with Tables 2-6. And the estimates for tariffs and transport costs are consistent with Tables 7-9. Thus, columns 3 and 4 in Table 10 indicate that profit sharing across borders is conditioned both by organizations and by trade barriers as well.

We briefly mention two other unreported robustness checks. First, to address possible concerns about endogeneity (see Section 3c) we estimated an instrumental-variables (IV) model by instrumenting for U.S. profits with exchange rates. Specifically, for each industry-year we constructed a trade-weighted multilateral U.S. exchange rate, where all relevant bilateral exchange rates are weighted by U.S. import shares. ${ }_{2}$ Exchange rates make good candidate instruments: they are correlated with profitability (as is commonly discussed in the financial media), yet are plausibly uncorrelated with the error term in equation (5). Thus, we estimated (5) using two-stage least squares (2SLS). Our 2SLS results were mixed: the overidentification tests

12 These industry-year exchange rates vary over time due to time-series exchange-rate movements, and also across industries due to different trading partners. Very similar results were obtained using export shares, as much U.S. trade is intra-industry. 
indicated profits are valid instruments, but we obtained very imprecise coefficient estimates due to poor first-stage regressions. Hausman specification tests failed to reject the null hypothesis of OLS consistency, so for brevity we have not reported IV estimates.

Second, our analysis has assumed that rent sharing of industry profits works through organizational structures of multinational firms and/or international unions at the bargaining-unit level. We also examined if these organizational structures matter at the industry level, to allow for the possibility that the industry presence of U.S. parents or unions might transmit U.S. profits into Canadian wage bargaining. On the corporate side, we constructed the fraction of (2-digit) industry sales in Canada accounted for by affiliates of U.S. multinationals. On the labor side, we created the fraction of union employees represented by international unions in each industry. These industry-level results broadly matched our bargaining-unit findings.

\section{Conclusions and Directions For Future Research}

Previous research has established that profits are shared: industry profits are robustly correlated with wages. In this paper we have asked whether profits are shared across borders, i.e., whether rent sharing extends across national borders, conditioned by corporate or labor organizational ties and/or by trade barriers. To answer this question, we combined wage data from a panel Canadian manufacturing collective bargaining agreements with data on industry profits for both Canada and the United States, data on whether each bargaining unit was owned by a Canadian or U.S. parent and was represented by a domestic or international union, and data on transportation costs and tariffs. Our main finding is yes, profits are shared across borders: there are international dimensions of rent sharing that have not been documented before.

First, international organizations matter. Consistent with earlier studies, there is strong evidence for rent sharing of Canadian industry profits. However, we found that this rent sharing is much less pronounced or even negative when a U.S. parent company and/or international union is involved. Moreover, we found that U.S. industry profits are negatively related to Canadian wages for domestic companies and unions, but that this effect is much less negative, or even positive, when a bargaining unit has a U.S. corporate and/or labor parent. This is consistent 
with strong industry profits in the United States placing downward pressure on Canadian wages because of product-market competition, while at the same time placing upward pressure on Canadian wages via international rent sharing in the presence of U.S. institutions that import U.S. conditions into Canadian collective bargaining.

Second, there is some evidence that border barriers matter as well. We analyzed the extent to which rent sharing of U.S. profits varies with trade protection. The results were weak for transportation costs, but higher Canadian tariffs mitigate the extent to which U.S. industry profits are negatively associated with Canadian wages.

Our findings raise possible directions for future work. We have offered explanations for our findings in terms of product-market competition, but we have not tested these explanations against possible alternatives. It would be ideal to have data on product-market profitability at different levels that might be relevant to wage setting, above and beyond our industry-level focus. And it would be interesting to examine whether the international linkages we documented hold for non-union wage settlements and/or for other countries.

Although we think these possible directions will be fruitful, we do think our findings for Canadian bargaining units reveal international aspects of profit sharing not previously documented. We interpret these findings as evidence of international rent sharing. As such, they are relevant for work on rent sharing and, more broadly, on how globalization conditions labormarket outcomes. Research on rent sharing would benefit from a more international perspective; research on globalization and labor markets would benefit from investigating issues of imperfect competition and institutions, above and beyond Heckscher-Ohlin considerations. ${ }_{4}$

13 Our findings may also relate to the international-macro literature on cross-country movements in macro aggregates (see Obstfeld and Rogoff, 2000, for a survey). It has been documented that Canada and the United States experience common movements in many macro aggregates. Using nine-variable vector autoregressions on monthly time-series data, Burbidge and Harrison (1985) find a positive response of Canadian industrial production following shocks to U.S. industrial production. Altonji and Ham (1990, S231), using annual time-series data across provinces and industries, conclude that U.S. aggregate gross national product shocks are "the dominant influence on aggregate employment growth in Canada." Our findings suggest that micro-level linkages such as multinational ownership and international unions may underlie these Canadian-U.S. macro co-movements. 


\section{References}

Abowd, John M., and Richard B. Freeman (eds). 1991. Immigration, Trade, and the Labor Market. Chicago: University of Chicago Press.

Abowd, John M., and Thomas Lemieux. 1991. "The Effects of International Competition on Collective Bargaining Outcomes: A Comparison of the United States and Canada." In John M. Abowd and Richard B. Freeman (eds.), Immigration, Trade, and the Labor Market. (Chicago: University of Chicago Press), pp. 343-367.

Abowd, John M., and Thomas Lemieux. 1993. "The Effects of Product Market Competition on Collective Bargaining Agreements: The Case of Foreign Competition in Canada." Quarterly Journal of Economics, Vol. 108 (4), November, pp. 983-1014.

Aitken, Brian, Ann Harrison, and Robert E. Lipsey. 1996. "Wages and Foreign Ownership: A Comparative Study of Mexico, Venezuela, and the United States." Journal of International Economics, Vol. 40 (3-4), May, pp. 345-371.

Altonji, Joseph G., and John C. Ham. 1990. "Variation in Employment Growth in Canada: The Role of External, National, Regional, and Industrial Factors." Journal of Labor Economics, Vol. 8 (1, Part 2), January, pp. S198-S236.

Bartelsman, Eric J., and Wayne Gray. 1996. "The NBER Manufacturing Productivity Database," National Bureau of Economic Research Technical Working Paper No. 205.

Blanchflower, David G., Andrew J. Oswald, and Peter Sanfey. 1996. "Wages, Profits, and RentSharing." Quarterly Journal of Economics, Vol. 111 (1), February, pp. 227-251.

Borjas, George J., and Valerie A. Ramey. 1995. "Foreign Competition, Market Power, and Wage Inequality." Quarterly Journal of Economics, Vol. 110 (4), November, pp. 1075-1110.

Budd, John W. 1998. "The Effect of International Unions on Wage Determination in Canada." British Journal of Industrial Relations, Vol. 36 (1), March, pp. 1-26.

Burbidge, John, and Alan Harrison. 1985. "(Innovation) Accounting for the Impact of Fluctuations in U.S. Variables on the Canadian Economy." Canadian Journal of Economics, Vol. 18 (4), November, pp. 784-798.

Christofides, Louis N., and Andrew J. Oswald. 1992. "Real Wage Determination and RentSharing in Collective Bargaining Agreements." Quarterly Journal of Economics, Vol. 107 (3), August, pp. 985-1002.

Crispo, John. 1967. International Unionism: A Study in Canadian-American Relations. Toronto: McGraw-Hill. 
Currie, Janet, and Sheena McConnell. 1992. "Firm-Specific Determinants of the Real Wage." The Review of Economics and Statistics, Vol. 74 (2), May, pp. 297-304.

Deardorff, Alan V. and Robert M. Stern. 1990. Computational Analysis of Global Trading Arrangements. Ann Arbor: The University of Michigan Press.

Doms, Mark E., and J. Bradford Jensen. 1998. "Comparing Wages, Skills, and Productivity between Domestically and Foreign-Owned Manufacturing Establishments in the United States." In Robert E. Baldwin, Richard E. Lipsey, and J. David Richardson (eds.), Geography and Ownership as Bases for Economic Accounting: NBER Studies in Income and Wealth, Volume 59. (Chicago, IL: University of Chicago Press), pp. 235-258.

Feenstra, Robert C. (ed). 2000. The Impact of International Trade On Wages. Chicago: The University of Chicago Press.

Feliciano, Zadia, and Robert E. Lipsey. 1999. "Foreign Ownership and Wages in the United States, 1987-1992." National Bureau of Economic Research Working Paper No. 6923.

Freeman, Richard B., and Lawrence F. Katz. 1991. "Industrial Wage and Employment Determination in an Open Economy." In John M. Abowd and Richard B. Freeman (eds.), Immigration, Trade, and the Labor Market. (Chicago: University of Chicago), pp. 235-259.

Gaston, Noel, and Daniel Trefler. 1994. "Protection, Trade, and Wages: Evidence from U.S. Manufacturing." Industrial and Labor Relations Review, Vol. 47 (4), July, pp. 574-593.

Gaston, Noel, and Daniel Trefler. 1995. "Union Wage Sensitivity To Trade and Protection: Theory and Evidence." Journal of International Economics, Vol. 39 (1-2), August, pp. 1-25.

Globerman, Steven, John C. Ries, and Ilan Vertinsky. 1994. "The Economic Performance of Foreign Affiliates in Canada," Canadian Journal of Economics, Vol. 27 (1), pp. 143-156.

Haskel, Jonathan E., and Matthew J. Slaughter. 2000. "Have Falling Tariffs and Transportation Costs Raised U.S. Wage Inequality?” NBER Working Paper No. 7539, February.

Helpman, Elhanan, and Paul R. Krugman. 1989. Market Structure and Foreign Trade. Cambridge: MIT Press.

Hildreth, Andrew K.G., and Andrew J. Oswald. 1997. "Rent-Sharing and Wages: Evidence from Company and Establishment Panels.” Journal of Labor Economics, Vol. 15 (2), pp. 318-337.

Hines, James R. 1996. "Dividends and Profits: Some Unsubtle Foreign Influences." Journal of Finance, Vol. 51 (2), June, pp. 661-689.

Howenstine, Ned G., and William J. Zeile. 1994. "Characteristics of Foreign-owned U.S. Manufacturing Establishments." Survey of Current Business, Vol. 74 (1), January, pp. 34-59. 
Katz, Lawrence F., and Lawrence H. Summers. 1989. "Industry Rents: Evidence and Implications." Brookings Papers on Economic Activity (Microeconomics), pp. 209-275.

Labour Canada. various issues. Collective Bargaining Review. Ottawa: Bureau of Labour Information.

Labour Canada. various issues. Directory of Labour Organizations in Canada. Ottawa: Labour Data Branch.

MacDonald, Robert M. 1963. Collective Bargaining in the Automobile Industry. New Haven: Yale University Press.

Magun, Sunder, Someshwar Rao, Bimal Lodh, Laval Lvallee, and Jonathan Pierce. 1988. "Open Borders: An Assessment of the Canada-U.S. Free Trade Agreement." Economic Council of Canada Discussion Paper No. 344.

Murphy, Kevin J. 1999. "Executive Compensation.” In Orley Ashenfelter and David Card (eds.), Handbook of Labor Economics, Volume 3, Amsterdam: North Holland.

Obstfeld, Maurice, and Kenneth Rogoff. 2000. “The Six Major Puzzles in International Macroeconomics: Is There a Common Cause?" National Bureau of Economic Research Working Paper No. 7777, July, forthcoming NBER Macroeconomics Annual 2000.

Oswald, Andrew J. 1996. "Rent-Sharing in the Labor Market." University of Warwick Department of Economics Research Paper No. 474, December.

Rodrik, Dani. 1997. Has Globalization Gone Too Far? Washington, D.C.: Institute for International Economics.

Slaughter, Matthew J. 1999. "Globalization and Wages: A Tale of Two Perspectives." World Economy, Vol. 22 (5), July, pp. 609-630.

Statistics Canada. 1991. Concordance Between the Standard Industrial Classifications of Canada and the United States (catalogue 12-574E). Ottawa: Minister of Supply and Services.

Svejnar, Jan. 1986. "Bargaining Power, Fear of Disagreement, and Wage Settlements: Theory and Evidence From U.S. Industry.” Econometrica, Vol. 54 (5), September, pp. 1055-1078.

Svejnar, Jan, and Stephen C. Smith. 1984. "The Economics of Joint Ventures in Less Developed Countries.” Quarterly Journal of Economics, Vol. 99 (1), February, pp. 149-168.

Ward's Communications. 1999. Ward's Motor Vehicle Facts and Figures. Southfield, MI.

Yates, Charlotte A.B. 1993. From Plant to Politics: The Autoworkers Union in Postwar Canada. Philadelphia: Temple University Press. 
Table 1

Canadian Union Contract Wage Settlements, 1980-92: Summary Statistics

\begin{tabular}{|c|c|c|c|c|}
\hline \multirow[b]{2}{*}{ Variable } & \multicolumn{3}{|c|}{$\underline{\text { Mean (Standard Deviation) }}$} & \multirow[b]{2}{*}{$\begin{array}{c}\begin{array}{c}\mathrm{t} \text {-test } \\
(\mathrm{p}-\mathrm{value})^{\mathrm{a}}\end{array} \\
(4)\end{array}$} \\
\hline & $\begin{array}{c}\begin{array}{c}\text { Full } \\
\text { Sample }\end{array} \\
(1)\end{array}$ & $\begin{array}{l}\text { Canadian } \\
\frac{\text { Parent }}{(2)}\end{array}$ & $\begin{array}{c}\text { U.S. } \\
\frac{\text { Parent }}{(3)}\end{array}$ & \\
\hline $\begin{array}{l}\text { Log Base Wage, Start of } \\
\text { Contract (1994 dollars) }\end{array}$ & $\begin{array}{c}2.468 \\
(0.222)\end{array}$ & $\begin{array}{c}2.477 \\
(0.233)\end{array}$ & $\begin{array}{l}2.455 \\
(0.204)\end{array}$ & $\begin{array}{c}1.625 \\
(0.105)\end{array}$ \\
\hline $\begin{array}{l}\text { Contract Duration } \\
\text { (months) }\end{array}$ & $\begin{array}{l}29.730 \\
(7.871)\end{array}$ & $\begin{array}{l}29.491 \\
(8.068)\end{array}$ & $\begin{array}{l}30.086 \\
(7.564)\end{array}$ & $\begin{array}{l}-1.195 \\
(0.232)\end{array}$ \\
\hline $\begin{array}{l}\text { Number of Employees } \\
\text { (thousands) }\end{array}$ & $\begin{array}{c}1.481 \\
(2.924)\end{array}$ & $\begin{array}{l}1.488 \\
(2.257)\end{array}$ & $\begin{array}{c}1.471 \\
(3.706)\end{array}$ & $\begin{array}{c}0.084 \\
(0.933)\end{array}$ \\
\hline $\begin{array}{l}\text { Log Industry Average Hourly } \\
\text { Earnings (1994 dollars) }\end{array}$ & $\begin{array}{c}2.534 \\
(0.173)\end{array}$ & $\begin{array}{c}2.542 \\
(0.189)\end{array}$ & $\begin{array}{l}2.523 \\
(0.147)\end{array}$ & $\begin{array}{c}1.794 \\
(0.073)\end{array}$ \\
\hline $\begin{array}{l}\text { Industry Employment Growth } \\
\text { (percent, preceding } 12 \text { months) }\end{array}$ & $\begin{array}{c}0.147 \\
(6.548)\end{array}$ & $\begin{array}{l}-0.209 \\
(6.028)\end{array}$ & $\begin{array}{c}0.679 \\
(7.229)\end{array}$ & $\begin{array}{l}-2.047 \\
(0.041)\end{array}$ \\
\hline Provincial Unemployment Rate & $\begin{array}{c}9.431 \\
(2.926)\end{array}$ & $\begin{array}{c}9.824 \\
(3.038)\end{array}$ & $\begin{array}{c}8.844 \\
(2.648)\end{array}$ & $\begin{array}{c}5.436 \\
(0.000)\end{array}$ \\
\hline $\begin{array}{l}\text { Log Provincial Average Weekly } \\
\text { Earnings (1994 dollars) }\end{array}$ & $\begin{array}{c}6.152 \\
(0.055)\end{array}$ & $\begin{array}{c}6.151 \\
(0.067)\end{array}$ & $\begin{array}{c}6.154 \\
(0.030)\end{array}$ & $\begin{array}{l}-0.820 \\
(0.412)\end{array}$ \\
\hline $\begin{array}{l}\text { Canadian Industry Profits Per } \\
\text { Employee (lagged two years; } \\
\text { billions of } 1992 \text { dollars) }\end{array}$ & $\begin{array}{c}0.036 \\
(0.020)\end{array}$ & $\begin{array}{c}0.035 \\
(0.021)\end{array}$ & $\begin{array}{c}0.037 \\
(0.019)\end{array}$ & $\begin{array}{c}-1.132 \\
(0.258)\end{array}$ \\
\hline $\begin{array}{l}\text { U.S. Industry Profits Per } \\
\text { Employee (lagged two years; } \\
\text { billions of } 1987 \text { dollars) }\end{array}$ & $\begin{array}{c}0.037 \\
(0.022)\end{array}$ & $\begin{array}{c}0.035 \\
(0.020)\end{array}$ & $\begin{array}{c}0.040 \\
(0.023)\end{array}$ & $\begin{array}{l}-3.621 \\
(0.000)\end{array}$ \\
\hline 1 if U.S. Parent & $\begin{array}{c}0.401 \\
(0.490)\end{array}$ & 0 & 1 & \\
\hline 1 if Canadian Multinational & $\begin{array}{c}0.275 \\
(0.447)\end{array}$ & $\begin{array}{c}0.460 \\
(0.499)\end{array}$ & 0 & \\
\hline 1 if International Union & $\begin{array}{c}0.531 \\
(0.499)\end{array}$ & $\begin{array}{c}0.527 \\
(0.500)\end{array}$ & $\begin{array}{c}0.536 \\
(0.499) \\
\end{array}$ & $\begin{array}{c}-0.264 \\
(0.792)\end{array}$ \\
\hline
\end{tabular}


Table 1 (continued)

\begin{tabular}{|c|c|c|c|c|}
\hline $\begin{array}{l}\text { Transportation Costs, Canada to } \\
\text { United States (Industry) }\end{array}$ & $\begin{array}{l}0.970 \\
(1.425)\end{array}$ & $\begin{array}{c}1.057 \\
(1.532)\end{array}$ & $\begin{array}{c}0.840 \\
(1.239)\end{array}$ & $\begin{array}{c}2.485 \\
(0.013)\end{array}$ \\
\hline $\begin{array}{l}\text { Ad Valorem Tariff Rate } \\
\text { (Industry) }\end{array}$ & $\begin{array}{l}7.175 \\
(5.167)\end{array}$ & $\begin{array}{c}7.372 \\
(5.398)\end{array}$ & $\begin{array}{c}6.882 \\
(4.794)\end{array}$ & $\begin{array}{c}1.516 \\
(0.130)\end{array}$ \\
\hline Sample Size & 1014 & 607 & 407 & \\
\hline
\end{tabular}

Source: see text

Notes: ${ }^{a}$ t-test for difference in means between column 2 and 3. 
Table 2

Regression Analysis of Canadian Union Contract Wage Settlements:

The Importance of U.S. Profits ${ }^{\mathrm{a}}$

\begin{tabular}{|c|c|c|c|c|c|c|}
\hline Variable & (1) & (2) & (3) & (4) & (5) & (6) \\
\hline $\begin{array}{l}\text { Contract Duration } \\
\text { (months) }\end{array}$ & $\begin{array}{c}0.003 \\
(0.001)\end{array}$ & $\begin{array}{c}0.003 \\
(0.001)\end{array}$ & $\begin{array}{c}0.003 \\
(0.001)\end{array}$ & $\begin{array}{c}0.003 \\
(0.001)\end{array}$ & $\begin{array}{c}0.003 \\
(0.001)\end{array}$ & $\begin{array}{c}0.003 \\
(0.001)\end{array}$ \\
\hline $\begin{array}{l}\text { Number of Employees } \\
\text { (thousands) }\end{array}$ & $\begin{array}{c}0.006 \\
(0.001)\end{array}$ & $\begin{array}{c}0.006 \\
(0.001)\end{array}$ & $\begin{array}{c}0.005 \\
(0.001)\end{array}$ & $\begin{array}{c}0.006 \\
(0.001)\end{array}$ & $\begin{array}{c}0.005 \\
(0.001)\end{array}$ & $\begin{array}{c}0.006 \\
(0.001)\end{array}$ \\
\hline $\begin{array}{l}\text { Log Industry Average Hourly } \\
\text { Earnings (1994 dollars) }\end{array}$ & $\begin{array}{l}-0.122 \\
(0.241)\end{array}$ & $\begin{array}{l}-0.105 \\
(0.243)\end{array}$ & $\begin{array}{l}-0.087 \\
(0.245)\end{array}$ & $\begin{array}{l}-0.037 \\
(0.244)\end{array}$ & $\begin{array}{l}-0.103 \\
(0.245)\end{array}$ & $\begin{array}{l}-0.054 \\
(0.245)\end{array}$ \\
\hline $\begin{array}{l}\text { Industry Employment Growth } \\
(\div 1000)\end{array}$ & $\begin{array}{l}-0.277 \\
(1.167)\end{array}$ & $\begin{array}{l}-0.190 \\
(1.168)\end{array}$ & $\begin{array}{c}-0.172 \\
(1.153)\end{array}$ & $\begin{array}{l}-0.274 \\
(1.138)\end{array}$ & $\begin{array}{l}-0.302 \\
(1.138)\end{array}$ & $\begin{array}{l}-0.407 \\
(1.123)\end{array}$ \\
\hline Provincial Unemployment Rate & $\begin{array}{c}0.005 \\
(0.004)\end{array}$ & $\begin{array}{c}0.005 \\
(0.004)\end{array}$ & $\begin{array}{c}0.005 \\
(0.004)\end{array}$ & $\begin{array}{c}0.005 \\
(0.004)\end{array}$ & $\begin{array}{c}0.004 \\
(0.004)\end{array}$ & $\begin{array}{r}0.004 \\
(0.004)\end{array}$ \\
\hline $\begin{array}{l}\text { Log Provincial Average Weekly } \\
\text { Earnings (1994 dollars) }\end{array}$ & $\begin{array}{c}0.441 \\
(0.231)\end{array}$ & $\begin{array}{c}0.445 \\
(0.232)\end{array}$ & $\begin{array}{c}0.429 \\
(0.232)\end{array}$ & $\begin{array}{c}0.462 \\
(0.228)\end{array}$ & $\begin{array}{c}0.370 \\
(0.234)\end{array}$ & $\begin{array}{c}0.408 \\
(0.231)\end{array}$ \\
\hline U.S. Parent & --- & --- & $\begin{array}{c}0.009 \\
(0.014)\end{array}$ & $\begin{array}{l}-0.022 \\
(0.028)\end{array}$ & $\begin{array}{c}0.006 \\
(0.014)\end{array}$ & $\begin{array}{c}0.022 \\
(0.029)\end{array}$ \\
\hline International Union & --- & --- & $\begin{array}{l}-0.048 \\
(0.016)\end{array}$ & $\begin{array}{l}-0.052 \\
(0.015)\end{array}$ & $\begin{array}{l}-0.041 \\
(0.026)\end{array}$ & $\begin{array}{l}-0.041 \\
(0.026)\end{array}$ \\
\hline $\begin{array}{l}\text { Lagged Canadian Industry } \\
\text { Profits (billions) }\end{array}$ & $\begin{array}{c}1.583 \\
(0.361)\end{array}$ & $\begin{array}{l}1.800 \\
(0.430)\end{array}$ & $\begin{array}{c}1.836 \\
(0.422)\end{array}$ & $\begin{array}{l}2.740 \\
(0.438)\end{array}$ & $\begin{array}{c}2.454 \\
(0.443)\end{array}$ & $\begin{array}{r}3.340 \\
(0.479)\end{array}$ \\
\hline Canadian Profits $\times$ U.S. Parent & --- & --- & --- & $\begin{array}{l}-1.708 \\
(0.675)\end{array}$ & --- & $\begin{array}{l}-1.704 \\
(0.687)\end{array}$ \\
\hline $\begin{array}{l}\text { Canadian Profits } \times \\
\text { International Union }\end{array}$ & --- & --- & --- & --- & $\begin{array}{l}-2.193 \\
(0.871)\end{array}$ & $\begin{array}{l}-2.157 \\
(0.853)\end{array}$ \\
\hline $\begin{array}{l}\text { Lagged U.S. Industry Profits } \\
\text { (billions) }\end{array}$ & --- & $\begin{array}{l}-0.525 \\
(0.446)\end{array}$ & $\begin{array}{l}-0.758 \\
(0.433)\end{array}$ & $\begin{array}{l}-2.093 \\
(0.436)\end{array}$ & $\begin{array}{l}-1.291 \\
(0.504)\end{array}$ & $\begin{array}{l}-2.543 \\
(0.508)\end{array}$ \\
\hline U.S. Profits $\times$ U.S. Parent & --- & --- & --- & $\begin{array}{c}2.399 \\
(0.666)\end{array}$ & --- & $\begin{array}{l}2.327 \\
(0.664)\end{array}$ \\
\hline $\begin{array}{l}\text { U.S. Profits } \times \\
\text { International Union }\end{array}$ & --- & --- & --- & --- & $\begin{array}{c}1.984 \\
(0.808)\end{array}$ & $\begin{array}{c}1.850 \\
(0.765)\end{array}$ \\
\hline $\mathrm{R}$ squared & 0.433 & 0.434 & 0.441 & 0.448 & 0.446 & 0.453 \\
\hline
\end{tabular}

Source: Collective bargaining agreements in Canadian manufacturing, 1980-1992.

Notes: ${ }^{a}$ Dependent Variable: Log Real Wage at the Start of the Contract. Standard errors (in parentheses) are robust to arbitrary forms of heteroskedasticity. Each regression also includes industry (15), province (9), and year (12) effects. Sample size is 1014. 
Table 3

Regression Analysis of Canadian Union Contract Wage Settlements: Robustness Checks for the Profit Interaction with U.S. Parent ${ }^{\mathrm{a}}$

\begin{tabular}{|c|c|c|c|c|c|c|}
\hline Variable & $\begin{array}{c}\text { Baseline } \\
\text { (Table 2) } \\
(1)\end{array}$ & $\begin{array}{c}\text { Profit \#2 } \\
3 \text { year lag } \\
\text { (2) }\end{array}$ & $\begin{array}{c}\text { Profit \#3 } \\
2 \text { year lag } \\
\quad(3)\end{array}$ & $\begin{array}{c}\text { U.S. Profits in } \\
\text { Canadian } \$ \\
(4)\end{array}$ & $\begin{array}{c}\text { Fixed Effects } \\
\text { (5) }\end{array}$ & $\begin{array}{c}\text { Excluding } \\
\text { Autos } \\
\text { (6) }\end{array}$ \\
\hline U.S. Parent & $\begin{array}{l}-0.022 \\
(0.028)\end{array}$ & $\begin{array}{l}-0.022 \\
(0.032)\end{array}$ & $\begin{array}{l}-0.011 \\
(0.028)\end{array}$ & $\begin{array}{l}-0.021 \\
(0.028)\end{array}$ & $\begin{array}{l}-0.009 \\
(0.014)\end{array}$ & $\begin{array}{l}-0.014 \\
(0.030)\end{array}$ \\
\hline $\begin{array}{l}\text { Lagged Canadian Industry } \\
\text { Profits (billions) }\end{array}$ & $\begin{array}{c}2.740 \\
(0.438)\end{array}$ & $\begin{array}{c}2.938 \\
(0.529)\end{array}$ & $\begin{array}{c}2.870 \\
(0.478)\end{array}$ & $\begin{array}{c}2.684 \\
(0.434)\end{array}$ & $\begin{array}{c}0.341 \\
(0.151)\end{array}$ & $\begin{array}{c}2.760 \\
(0.440)\end{array}$ \\
\hline Canadian Profits $\times$ U.S. Parent & $\begin{array}{l}-1.708 \\
(0.675)\end{array}$ & $\begin{array}{l}-1.709 \\
(0.729)\end{array}$ & $\begin{array}{l}-1.939 \\
(0.728)\end{array}$ & $\begin{array}{l}-1.658 \\
(0.671)\end{array}$ & $\begin{array}{l}-0.060 \\
(0.212)\end{array}$ & $\begin{array}{l}-1.627 \\
(0.694)\end{array}$ \\
\hline $\begin{array}{l}\text { Lagged U.S. Industry Profits } \\
\text { (billions) }\end{array}$ & $\begin{array}{l}-2.093 \\
(0.436)\end{array}$ & $\begin{array}{l}-2.214 \\
(0.485)\end{array}$ & $\begin{array}{l}-2.033 \\
(0.428)\end{array}$ & $\begin{array}{l}-1.640 \\
(0.347)\end{array}$ & $\begin{array}{l}-0.437 \\
(0.224)\end{array}$ & $\begin{array}{l}-1.898 \\
(0.439)\end{array}$ \\
\hline U.S. Profits $\times$ U.S. Parent & $\begin{array}{c}2.399 \\
(0.666)\end{array}$ & $\begin{array}{c}2.485 \\
(0.737)\end{array}$ & $\begin{array}{c}2.296 \\
(0.632)\end{array}$ & $\begin{array}{c}1.884 \\
(0.539)\end{array}$ & $\begin{array}{c}0.402 \\
(0.294)\end{array}$ & $\begin{array}{c}2.184 \\
(0.685)\end{array}$ \\
\hline $\begin{array}{l}\text { R squared } \\
\text { Sample Size }\end{array}$ & $\begin{array}{c}0.448 \\
1014\end{array}$ & $\begin{array}{l}0.445 \\
892\end{array}$ & $\begin{array}{r}0.447 \\
1014\end{array}$ & $\begin{array}{l}0.448 \\
1014\end{array}$ & $\begin{array}{c}0.977 \\
927\end{array}$ & $\begin{array}{c}0.465 \\
923\end{array}$ \\
\hline
\end{tabular}

Source: Collective bargaining agreements in Canadian manufacturing, 1980-1992.

Notes: ${ }^{a}$ Dependent Variable: Log Real Wage at the Start of the Contract. Standard errors (in parentheses) are robust to arbitrary forms of heteroskedasticity. Each regression also includes the control variables from Table 2. 
Table 4

Regression Analysis of Canadian Union Contract Wage Settlements: Robustness Checks for the Profit Interaction with International Union ${ }^{\text {a }}$

\begin{tabular}{|c|c|c|c|c|c|c|}
\hline Variable & $\begin{array}{c}\text { Baseline } \\
\text { (Table 2) } \\
(1)\end{array}$ & $\begin{array}{c}\text { Profit \#2 } \\
3 \text { year lag } \\
(2)\end{array}$ & $\begin{array}{c}\text { Profit \#3 } \\
2 \text { year lag } \\
(3)\end{array}$ & $\begin{array}{c}\text { U.S. Profits in } \\
\text { Canadian } \$ \\
(4)\end{array}$ & $\begin{array}{c}\text { Fixed Effects } \\
(5)\end{array}$ & $\begin{array}{c}\text { Excluding } \\
\text { Autos } \\
(6)\end{array}$ \\
\hline International Union & $\begin{array}{l}-0.041 \\
(0.026)\end{array}$ & $\begin{array}{l}-0.033 \\
(0.030)\end{array}$ & $\begin{array}{l}-0.038 \\
(0.026)\end{array}$ & $\begin{array}{l}-0.040 \\
(0.026)\end{array}$ & $\begin{array}{l}-0.031 \\
(0.010)\end{array}$ & $\begin{array}{l}-0.034 \\
(0.026)\end{array}$ \\
\hline $\begin{array}{l}\text { Lagged Canadian Industry } \\
\text { Profits (billions) }\end{array}$ & $\begin{array}{c}2.454 \\
(0.443)\end{array}$ & $\begin{array}{c}2.600 \\
(0.456)\end{array}$ & $\begin{array}{c}2.439 \\
(0.487)\end{array}$ & $\begin{array}{c}2.428 \\
(0.440)\end{array}$ & $\begin{array}{c}0.335 \\
(0.156)\end{array}$ & $\begin{array}{c}2.453 \\
(0.458)\end{array}$ \\
\hline $\begin{array}{l}\text { Canadian Profits } \times \\
\text { International Union }\end{array}$ & $\begin{array}{l}-2.193 \\
(0.871)\end{array}$ & $\begin{array}{l}-2.901 \\
(1.064)\end{array}$ & $\begin{array}{l}-2.033 \\
(0.928)\end{array}$ & $\begin{array}{l}-2.159 \\
(0.874)\end{array}$ & $\begin{array}{l}-0.024 \\
(0.284)\end{array}$ & $\begin{array}{l}-1.784 \\
(0.870)\end{array}$ \\
\hline $\begin{array}{l}\text { Lagged U.S. Industry Profits } \\
\text { (billions) }\end{array}$ & $\begin{array}{l}-1.291 \\
(0.504)\end{array}$ & $\begin{array}{l}-1.342 \\
(0.563)\end{array}$ & $\begin{array}{l}-1.223 \\
(0.494)\end{array}$ & $\begin{array}{l}-1.021 \\
(0.408)\end{array}$ & $\begin{array}{l}-0.334 \\
(0.221)\end{array}$ & $\begin{array}{l}-1.241 \\
(0.508)\end{array}$ \\
\hline $\begin{array}{l}\text { U.S. Profits } \times \\
\text { International Union }\end{array}$ & $\begin{array}{c}1.984 \\
(0.808)\end{array}$ & $\begin{array}{c}2.423 \\
(0.895)\end{array}$ & $\begin{array}{c}1.624 \\
(0.765)\end{array}$ & $\begin{array}{c}1.564 \\
(0.662)\end{array}$ & $\begin{array}{c}0.104 \\
(0.424)\end{array}$ & $\begin{array}{c}1.944 \\
(0.806)\end{array}$ \\
\hline $\begin{array}{l}\text { R squared } \\
\text { Sample Size }\end{array}$ & $\begin{array}{c}0.446 \\
1014\end{array}$ & $\begin{array}{c}0.445 \\
892\end{array}$ & $\begin{array}{c}0.444 \\
1014\end{array}$ & $\begin{array}{c}0.446 \\
1014\end{array}$ & $\begin{array}{c}0.977 \\
927\end{array}$ & $\begin{array}{c}0.464 \\
923\end{array}$ \\
\hline
\end{tabular}

Source: Collective bargaining agreements in Canadian manufacturing, 1980-1992.

Notes: ${ }^{a}$ Dependent Variable: Log Real Wage at the Start of the Contract. Standard errors (in parentheses) are robust to arbitrary forms of heteroskedasticity. Each regression also includes the control variables from Table 2. 
Table 5

Regression Analysis of Canadian Union Contract Wage Settlements:

Separate Sample Regressions ${ }^{\mathrm{a}}$

\begin{tabular}{|c|c|c|c|c|}
\hline Variable & $\begin{array}{c}\text { Canadian } \\
\text { Parents } \\
(1)\end{array}$ & $\begin{array}{c}\text { U.S. } \\
\text { Parents } \\
(2)\end{array}$ & $\begin{array}{c}\text { Canadian } \\
\text { Unions } \\
(3)\end{array}$ & $\begin{array}{c}\text { International } \\
\text { Unions } \\
(4)\end{array}$ \\
\hline U.S. Parent & --- & --- & $\begin{array}{l}0.075 \\
(0.014)\end{array}$ & $\begin{array}{l}-0.019 \\
(0.023)\end{array}$ \\
\hline International Union & $\begin{array}{l}-0.024 \\
(0.017)\end{array}$ & $\begin{array}{l}-0.147 \\
(0.022)\end{array}$ & --- & --- \\
\hline $\begin{array}{l}\text { Lagged Canadian Industry } \\
\text { Profits (billions) }\end{array}$ & $\begin{array}{c}2.250 \\
(0.464)\end{array}$ & $\begin{array}{c}0.026 \\
(0.604)\end{array}$ & $\begin{array}{c}2.046 \\
(0.388)\end{array}$ & $\begin{array}{c}0.264 \\
(0.772)\end{array}$ \\
\hline $\begin{array}{l}\text { Lagged U.S. Industry Profits } \\
\text { (billions) }\end{array}$ & $\begin{array}{l}-1.102 \\
(0.434)\end{array}$ & $\begin{array}{c}0.920 \\
(0.480)\end{array}$ & $\begin{array}{l}-0.595 \\
(0.409)\end{array}$ & $\begin{array}{c}1.132 \\
(0.692)\end{array}$ \\
\hline $\begin{array}{l}\text { R squared } \\
\text { Sample Size }\end{array}$ & $\begin{array}{c}0.600 \\
607\end{array}$ & $\begin{array}{c}0.568 \\
407\end{array}$ & $\begin{array}{c}0.664 \\
476 \\
\end{array}$ & $\begin{array}{c}0.496 \\
538 \\
\end{array}$ \\
\hline
\end{tabular}

Source: Collective bargaining agreements in Canadian manufacturing, 1980-1992.

Notes: ${ }^{a}$ Dependent Variable: Log Real Wage at the Start of the Contract. Standard errors (in parentheses) are robust to arbitrary forms of heteroskedasticity. Each regression also includes the control variables from Table 2 . 
Table 6

Regression Analysis of Canadian Union Contract Wage Settlements: Canadian Multinational Parents and U.S. Parents with International Unions ${ }^{\mathrm{a}}$

\begin{tabular}{|c|c|c|}
\hline Variable & (1) & $(2)$ \\
\hline $\begin{array}{l}\text { Canadian Multinational } \\
\text { Parent }\end{array}$ & $\begin{array}{l}-0.162 \\
(0.031)\end{array}$ & --- \\
\hline U.S. Parent & $\begin{array}{l}-0.106 \\
(0.016)\end{array}$ & $\begin{array}{c}0.049 \\
(0.016)\end{array}$ \\
\hline International Union & $\begin{array}{l}-0.054 \\
(0.015)\end{array}$ & $\begin{array}{l}-0.012 \\
(0.017)\end{array}$ \\
\hline $\begin{array}{l}\text { U.S. Parent and } \\
\text { International Union }\end{array}$ & --- & $\begin{array}{l}-0.114 \\
(0.043)\end{array}$ \\
\hline $\begin{array}{l}\text { Lagged Canadian Industry } \\
\text { Profits (billions) }\end{array}$ & $\begin{array}{l}1.559 \\
(0.583)\end{array}$ & $\begin{array}{c}2.490 \\
(0.393)\end{array}$ \\
\hline $\begin{array}{l}\text { Canadian Profits } \times \text { Canadian } \\
\text { Multinational Parent }\end{array}$ & $\begin{array}{l}2.374 \\
(0.701)\end{array}$ & --- \\
\hline $\begin{array}{l}\text { Canadian Profits } \times \\
\text { U.S. Parent }\end{array}$ & $\begin{array}{l}-0.544 \\
(0.779)\end{array}$ & --- \\
\hline $\begin{array}{l}\text { Canadian Profits } \times(\text { U.S. } \\
\text { Parent and International } \\
\text { Union })\end{array}$ & --- & $\begin{array}{l}-4.483 \\
(1.441)\end{array}$ \\
\hline $\begin{array}{l}\text { Lagged U.S. Industry Profits } \\
\text { (billions) }\end{array}$ & $\begin{array}{l}-2.477 \\
(0.723)\end{array}$ & $\begin{array}{l}-1.579 \\
(0.438)\end{array}$ \\
\hline $\begin{array}{l}\text { U.S. Profits } \times \text { Canadian } \\
\text { Multinational Parent }\end{array}$ & $\begin{array}{c}0.708 \\
(0.855)\end{array}$ & --- \\
\hline $\begin{array}{l}\text { U.S. Profits } \times \\
\text { U.S. Parent }\end{array}$ & $\begin{array}{c}2.863 \\
(0.868)\end{array}$ & --- \\
\hline $\begin{array}{l}\text { U.S. Profits } \times(\text { U.S. Parent } \\
\text { and International Union })\end{array}$ & --- & $\begin{array}{c}5.136 \\
(1.006)\end{array}$ \\
\hline R Squared & 0.462 & 0.467 \\
\hline \multicolumn{3}{|c|}{$\begin{array}{l}\text { Source: Collective bargaining agreements in Canadian manufacturing, 1980-1992. } \\
\text { Notes: }{ }^{\text {a }} \text { Dependent Variable: Log Real Wage at the Start of the Contract. } \\
\text { Standard errors (in parentheses) are robust to arbitrary forms of } \\
\text { heteroskedasticity. The regression also includes the control variables from } \\
\text { Table 2. Sample size is } 1014 \text {. }\end{array}$} \\
\hline
\end{tabular}


Table 7

Regression Analysis of Canadian Union Contract Wage Settlements: Profits and Trade Barriers ${ }^{\mathrm{a}}$

\begin{tabular}{|c|c|c|c|c|c|}
\hline Variable & $(1)$ & $(2)$ & (3) & (4) & $(5)$ \\
\hline Trade Barrier Variable: & N/A & \multicolumn{2}{|c|}{$\begin{array}{l}\text { Transportation Costs } \\
\text { From Canada to U.S. }\end{array}$} & \multicolumn{2}{|c|}{ Ad Valorem Tariff Rate } \\
\hline U.S Parent & $\begin{array}{c}0.009 \\
(0.014)\end{array}$ & $\begin{array}{c}0.007 \\
(0.014)\end{array}$ & $\begin{array}{c}0.007 \\
(0.014)\end{array}$ & $\begin{array}{c}0.009 \\
(0.014)\end{array}$ & $\begin{array}{c}0.016 \\
(0.014)\end{array}$ \\
\hline International Union & $\begin{array}{l}-0.048 \\
(0.016)\end{array}$ & $\begin{array}{l}-0.054 \\
(0.015)\end{array}$ & $\begin{array}{l}-0.054 \\
(0.015)\end{array}$ & $\begin{array}{l}-0.049 \\
(0.015)\end{array}$ & $\begin{array}{l}-0.048 \\
(0.015)\end{array}$ \\
\hline Trade Barrier variable & & $\begin{array}{c}0.034 \\
(0.007)\end{array}$ & $\begin{array}{c}0.034 \\
(0.010)\end{array}$ & $\begin{array}{l}-0.002 \\
(0.006)\end{array}$ & $\begin{array}{l}-0.009 \\
(0.007)\end{array}$ \\
\hline $\begin{array}{l}\text { Lagged Canadian Industry } \\
\text { Profits (billions) }\end{array}$ & $\begin{array}{c}1.836 \\
(0.422)\end{array}$ & $\begin{array}{l}1.478 \\
(0.429)\end{array}$ & $\begin{array}{l}1.388 \\
(0.619)\end{array}$ & $\begin{array}{c}1.829 \\
(0.423)\end{array}$ & $\begin{array}{l}3.239 \\
(0.981)\end{array}$ \\
\hline $\begin{array}{l}\text { Canadian Profits } \times \\
\text { Trade Barrier }\end{array}$ & --- & --- & $\begin{array}{c}0.056 \\
(0.219)\end{array}$ & --- & $\begin{array}{l}-0.121 \\
(0.137)\end{array}$ \\
\hline $\begin{array}{l}\text { Lagged U.S. Industry Profits } \\
\text { (billions) }\end{array}$ & $\begin{array}{l}-0.758 \\
(0.433)\end{array}$ & $\begin{array}{l}-1.092 \\
(0.439)\end{array}$ & $\begin{array}{l}-1.032 \\
(0.552)\end{array}$ & $\begin{array}{l}-0.775 \\
(0.438)\end{array}$ & $\begin{array}{l}-3.486 \\
(0.960)\end{array}$ \\
\hline $\begin{array}{l}\text { U.S. Profits } \times \\
\text { Trade Barrier }\end{array}$ & --- & --- & $\begin{array}{l}-0.048 \\
(0.203)\end{array}$ & --- & $\begin{array}{c}0.298 \\
(0.088)\end{array}$ \\
\hline $\mathrm{R}$ squared & 0.441 & 0.455 & 0.455 & 0.441 & 0.451 \\
\hline
\end{tabular}

Source: Collective bargaining agreements in Canadian manufacturing, 1980-1992.

Notes: ${ }^{a}$ Dependent Variable: Log Real Wage at the Start of the Contract. Standard errors (in parentheses) are robust to arbitrary forms of heteroskedasticity. Each regression also includes the control variables from Table 2. Sample size is 1014.

Column 1 is repeated from column 3 of Table 2 for comparison. 
Table 8

Regression Analysis of Canadian Union Contract Wage Settlements: Robustness Checks for the Profit Interaction with Transportation Costs ${ }^{\mathrm{a}}$

\begin{tabular}{|c|c|c|c|c|c|c|}
\hline Variable & $\begin{array}{c}\text { Baseline } \\
\text { (Table 7) } \\
(1)\end{array}$ & $\begin{array}{c}\text { Profit \#2 } \\
3 \text { year lag } \\
\text { (2) }\end{array}$ & $\begin{array}{c}\text { Profit \#3 } \\
2 \text { year lag } \\
\text { (3) }\end{array}$ & $\begin{array}{c}\text { U.S. Profits in } \\
\text { Canadian \$ } \\
\text { (4) }\end{array}$ & $\begin{array}{l}\text { Fixed Effects } \\
\text { (5) }\end{array}$ & $\begin{array}{c}\text { Excluding } \\
\text { Autos } \\
\text { (6) }\end{array}$ \\
\hline Transportation Costs & $\begin{array}{c}0.034 \\
(0.010)\end{array}$ & $\begin{array}{c}0.043 \\
(0.010)\end{array}$ & $\begin{array}{c}0.029 \\
(0.010)\end{array}$ & $\begin{array}{c}0.034 \\
(0.010)\end{array}$ & $\begin{array}{l}-0.010 \\
(0.004)\end{array}$ & $\begin{array}{c}0.036 \\
(0.010)\end{array}$ \\
\hline $\begin{array}{l}\text { Lagged Canadian Industry } \\
\text { Profits (billions) }\end{array}$ & $\begin{array}{c}1.388 \\
(0.619)\end{array}$ & $\begin{array}{l}2.156 \\
(0.605)\end{array}$ & $\begin{array}{c}0.987 \\
(0.623)\end{array}$ & $\begin{array}{c}1.368 \\
(0.619)\end{array}$ & $\begin{array}{c}0.279 \\
(0.167)\end{array}$ & $\begin{array}{l}1.793 \\
(0.647)\end{array}$ \\
\hline $\begin{array}{l}\text { Canadian Profits } \times \\
\text { Transportation Costs }\end{array}$ & $\begin{array}{c}0.056 \\
(0.219)\end{array}$ & $\begin{array}{l}-0.348 \\
(0.253)\end{array}$ & $\begin{array}{c}0.349 \\
(0.212)\end{array}$ & $\begin{array}{c}0.063 \\
(0.222)\end{array}$ & $\begin{array}{c}0.014 \\
(0.063)\end{array}$ & $\begin{array}{l}-0.085 \\
(0.216)\end{array}$ \\
\hline $\begin{array}{l}\text { Lagged U.S. Industry Profits } \\
\text { (billions) }\end{array}$ & $\begin{array}{l}-1.032 \\
(0.552)\end{array}$ & $\begin{array}{l}-1.305 \\
(0.598)\end{array}$ & $\begin{array}{l}-1.004 \\
(0.527)\end{array}$ & $\begin{array}{l}-0.810 \\
(0.439)\end{array}$ & $\begin{array}{l}-0.426 \\
(0.230)\end{array}$ & $\begin{array}{l}-1.042 \\
(0.557)\end{array}$ \\
\hline $\begin{array}{l}\text { U.S. Profits } \times \\
\text { Transportation Costs }\end{array}$ & $\begin{array}{l}-0.048 \\
(0.203)\end{array}$ & $\begin{array}{c}0.175 \\
(0.282)\end{array}$ & $\begin{array}{l}-0.124 \\
(0.168)\end{array}$ & $\begin{array}{l}-0.050 \\
(0.169)\end{array}$ & $\begin{array}{c}0.082 \\
(0.063)\end{array}$ & $\begin{array}{c}0.016 \\
(0.199)\end{array}$ \\
\hline $\begin{array}{l}\text { R squared } \\
\text { Sample Size }\end{array}$ & $\begin{array}{l}0.455 \\
1014\end{array}$ & $\begin{array}{c}0.451 \\
892\end{array}$ & $\begin{array}{c}0.456 \\
1014\end{array}$ & $\begin{array}{l}0.455 \\
1014\end{array}$ & $\begin{array}{c}0.977 \\
927\end{array}$ & $\begin{array}{c}0.473 \\
923\end{array}$ \\
\hline
\end{tabular}

Source: Collective bargaining agreements in Canadian manufacturing, 1980-1992.

Notes: ${ }^{a}$ Dependent Variable: Log Real Wage at the Start of the Contract. Standard errors (in parentheses) are robust to arbitrary forms of heteroskedasticity. Each regression also includes the control variables from Table 2. 
Table 9

Regression Analysis of Canadian Union Contract Wage Settlements: Robustness Checks for the Profit Interaction with the Tariff Rate ${ }^{\mathrm{a}}$

\begin{tabular}{|c|c|c|c|c|c|c|}
\hline Variable & $\begin{array}{c}\text { Baseline } \\
\text { (Table 7) } \\
(1)\end{array}$ & $\begin{array}{c}\text { Profit \#2 } \\
3 \text { year lag } \\
\text { (2) }\end{array}$ & $\begin{array}{c}\text { Profit \#3 } \\
2 \text { year lag } \\
\text { (3) }\end{array}$ & $\begin{array}{c}\text { U.S. Profits in } \\
\text { Canadian \$ } \\
(4)\end{array}$ & $\begin{array}{l}\text { Fixed Effects } \\
\text { (5) }\end{array}$ & $\begin{array}{c}\text { Excluding } \\
\text { Autos } \\
(6)\end{array}$ \\
\hline Ad Valorem Tariff Rate & $\begin{array}{l}-0.009 \\
(0.007)\end{array}$ & $\begin{array}{l}-0.009 \\
(0.008)\end{array}$ & $\begin{array}{l}-0.008 \\
(0.007)\end{array}$ & $\begin{array}{l}-0.008 \\
(0.007)\end{array}$ & $\begin{array}{l}-0.001 \\
(0.002)\end{array}$ & $\begin{array}{l}-0.011 \\
(0.009)\end{array}$ \\
\hline $\begin{array}{l}\text { Lagged Canadian Industry } \\
\text { Profits (billions) }\end{array}$ & $\begin{array}{l}3.239 \\
(0.981)\end{array}$ & $\begin{array}{c}2.371 \\
(0.842)\end{array}$ & $\begin{array}{c}3.038 \\
(1.012)\end{array}$ & $\begin{array}{c}3.308 \\
(0.980)\end{array}$ & $\begin{array}{l}-0.010 \\
(0.261)\end{array}$ & $\begin{array}{c}3.697 \\
(1.021)\end{array}$ \\
\hline $\begin{array}{l}\text { Canadian Profits } \times \\
\text { Tariff Rate }\end{array}$ & $\begin{array}{l}-0.121 \\
(0.137)\end{array}$ & $\begin{array}{c}0.047 \\
(0.130)\end{array}$ & $\begin{array}{l}-0.114 \\
(0.149)\end{array}$ & $\begin{array}{l}-0.131 \\
(0.137)\end{array}$ & $\begin{array}{c}0.049 \\
(0.036)\end{array}$ & $\begin{array}{l}-0.156 \\
(0.144)\end{array}$ \\
\hline $\begin{array}{l}\text { Lagged U.S. Industry Profits } \\
\text { (billions) }\end{array}$ & $\begin{array}{l}-3.486 \\
(0.960)\end{array}$ & $\begin{array}{l}-3.269 \\
(0.954)\end{array}$ & $\begin{array}{l}-3.086 \\
(0.893)\end{array}$ & $\begin{array}{l}-2.882 \\
(0.775)\end{array}$ & $\begin{array}{l}-0.042 \\
(0.298)\end{array}$ & $\begin{array}{l}-3.727 \\
(0.958)\end{array}$ \\
\hline $\begin{array}{l}\text { U.S. Profits } \times \\
\text { Tariff Rate }\end{array}$ & $\begin{array}{c}0.298 \\
(0.088)\end{array}$ & $\begin{array}{c}0.292 \\
(0.092)\end{array}$ & $\begin{array}{c}0.264 \\
(0.087)\end{array}$ & $\begin{array}{c}0.246 \\
(0.071)\end{array}$ & $\begin{array}{l}-0.042 \\
(0.050)\end{array}$ & $\begin{array}{c}0.321 \\
(0.088)\end{array}$ \\
\hline $\begin{array}{l}\text { R squared } \\
\text { Sample Size }\end{array}$ & $\begin{array}{c}0.451 \\
1014\end{array}$ & $\begin{array}{c}0.449 \\
892\end{array}$ & $\begin{array}{c}0.448 \\
1014\end{array}$ & $\begin{array}{l}0.451 \\
1014\end{array}$ & $\begin{array}{c}0.977 \\
927\end{array}$ & $\begin{array}{c}0.471 \\
923\end{array}$ \\
\hline
\end{tabular}

Source: Collective bargaining agreements in Canadian manufacturing, 1980-1992.

Notes: ${ }^{a}$ Dependent Variable: Log Real Wage at the Start of the Contract. Standard errors (in parentheses) are robust to arbitrary forms of heteroskedasticity. Each regression also includes the control variables from Table 2. 
Table 10

Regression Analysis of Canadian Union Contract Wage Settlements:

Profits, Multinational Organizations, and Trade Barriers ${ }^{\mathrm{a}}$

\begin{tabular}{|c|c|c|c|c|}
\hline Variable & (1) & $(2)$ & (3) & $(4)$ \\
\hline Trade Barrier Variable: & \multicolumn{2}{|c|}{$\begin{array}{l}\text { Transportation Costs } \\
\text { From Canada to U.S. }\end{array}$} & \multicolumn{2}{|c|}{ Ad Valorem Tariff Rate } \\
\hline U.S. Parent & $\begin{array}{l}-0.021 \\
(0.029)\end{array}$ & $\begin{array}{c}0.004 \\
(0.014)\end{array}$ & $\begin{array}{l}-0.016 \\
(0.028)\end{array}$ & $\begin{array}{c}0.013 \\
(0.014)\end{array}$ \\
\hline International Union & $\begin{array}{l}-0.057 \\
(0.015)\end{array}$ & $\begin{array}{l}-0.049 \\
(0.028)\end{array}$ & $\begin{array}{l}-0.051 \\
(0.015)\end{array}$ & $\begin{array}{l}-0.047 \\
(0.026)\end{array}$ \\
\hline Trade Barrier Variable & $\begin{array}{c}0.035 \\
(0.010)\end{array}$ & $\begin{array}{c}0.036 \\
(0.011)\end{array}$ & $\begin{array}{l}-0.010 \\
(0.007)\end{array}$ & $\begin{array}{l}-0.009 \\
(0.007)\end{array}$ \\
\hline $\begin{array}{l}\text { Lagged Canadian Industry } \\
\text { Profits (billions) }\end{array}$ & $\begin{array}{c}2.131 \\
(0.580)\end{array}$ & $\begin{array}{c}2.072 \\
(0.645)\end{array}$ & $\begin{array}{c}3.749 \\
(0.978)\end{array}$ & $\begin{array}{c}4.640 \\
(1.039)\end{array}$ \\
\hline Canadian Profits $\times$ U.S. Parent & $\begin{array}{l}-1.714 \\
(0.711)\end{array}$ & --- & $\begin{array}{l}-1.378 \\
(0.701)\end{array}$ & --- \\
\hline $\begin{array}{l}\text { Canadian Profits } \times \\
\text { International Union }\end{array}$ & --- & $\begin{array}{l}-2.319 \\
(0.881)\end{array}$ & --- & $\begin{array}{l}-2.842 \\
(0.889)\end{array}$ \\
\hline $\begin{array}{l}\text { Canadian Profits } \times \\
\text { Trade Barrier Variable }\end{array}$ & $\begin{array}{c}0.172 \\
(0.222)\end{array}$ & $\begin{array}{c}0.036 \\
(0.233)\end{array}$ & $\begin{array}{l}-0.095 \\
(0.138)\end{array}$ & $\begin{array}{l}-0.197 \\
(0.134)\end{array}$ \\
\hline $\begin{array}{l}\text { Lagged U.S. Industry Profits } \\
\text { (billions) }\end{array}$ & $\begin{array}{l}-2.141 \\
(0.499)\end{array}$ & $\begin{array}{l}-1.627 \\
(0.621)\end{array}$ & $\begin{array}{l}-4.351 \\
(0.930)\end{array}$ & $\begin{array}{l}-4.879 \\
(1.036)\end{array}$ \\
\hline U.S. Profits $\times$ U.S. Parent & $\begin{array}{c}2.330 \\
(0.682)\end{array}$ & --- & $\begin{array}{c}2.080 \\
(0.693)\end{array}$ & --- \\
\hline $\begin{array}{l}\text { U.S. Profits } \times \\
\text { International Union }\end{array}$ & --- & $\begin{array}{l}2.175 \\
(0.828)\end{array}$ & --- & $\begin{array}{c}2.834 \\
(0.855)\end{array}$ \\
\hline $\begin{array}{l}\text { U.S. Profits } \times \\
\text { Trade Barrier Variable }\end{array}$ & $\begin{array}{l}-0.185 \\
(0.199)\end{array}$ & $\begin{array}{l}-0.050 \\
(0.206)\end{array}$ & $\begin{array}{c}0.267 \\
(0.090)\end{array}$ & $\begin{array}{c}0.358 \\
(0.088)\end{array}$ \\
\hline $\mathrm{R}$ squared & 0.461 & 0.461 & 0.456 & 0.460 \\
\hline
\end{tabular}

Source: Collective bargaining agreements in Canadian manufacturing, 1980-1992.

Notes: ${ }^{a}$ Dependent Variable: Log Real Wage at the Start of the Contract. Standard errors (in parentheses) are robust to arbitrary forms of heteroskedasticity. Each regression also includes the control variables from Table 2. Sample size is 1014. 